Historic, Archive Document

Do not assume content reflects current scientific knowledge, policies, or practices. 



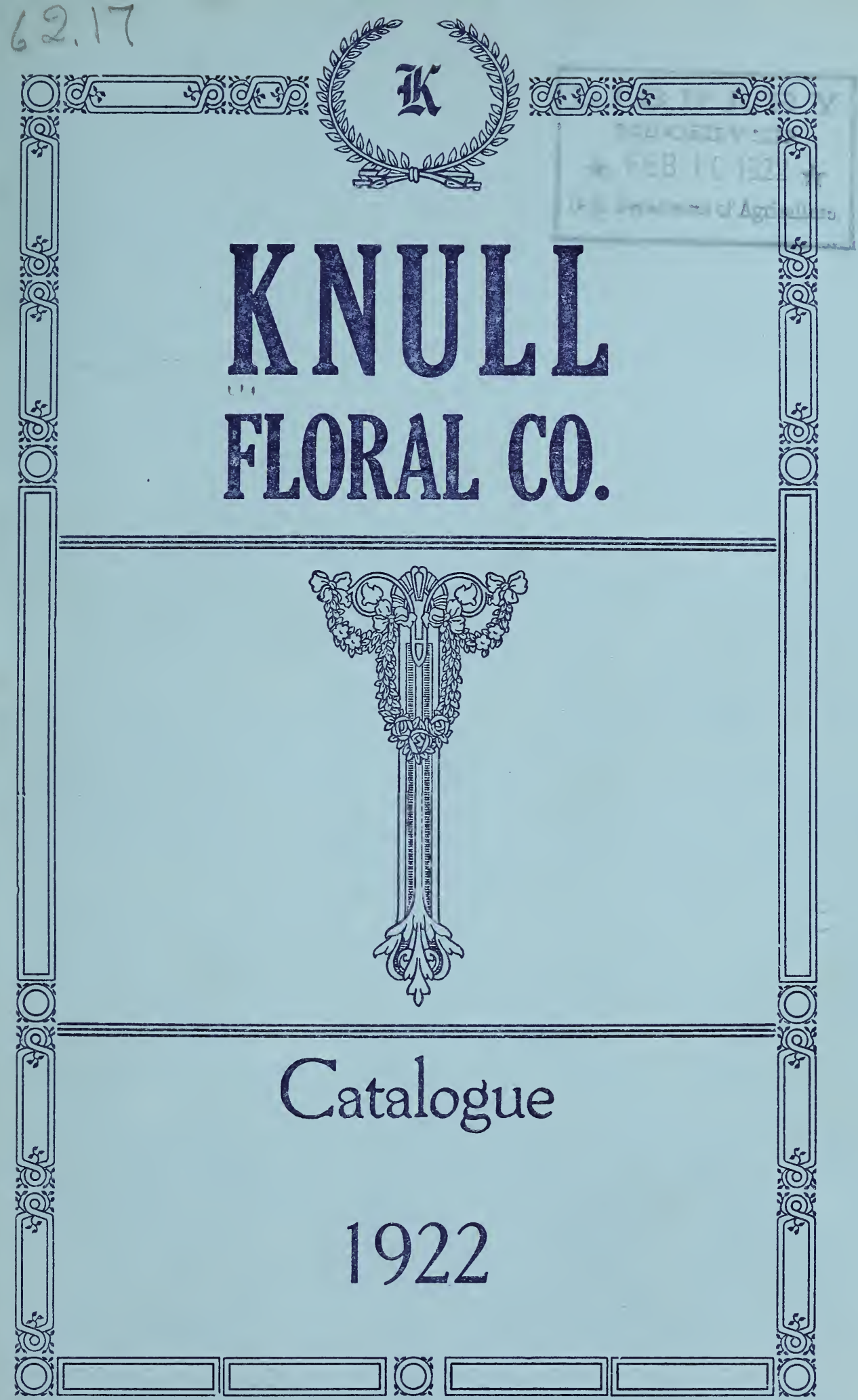





\section{"SAY IT WITH FLOWERS"}

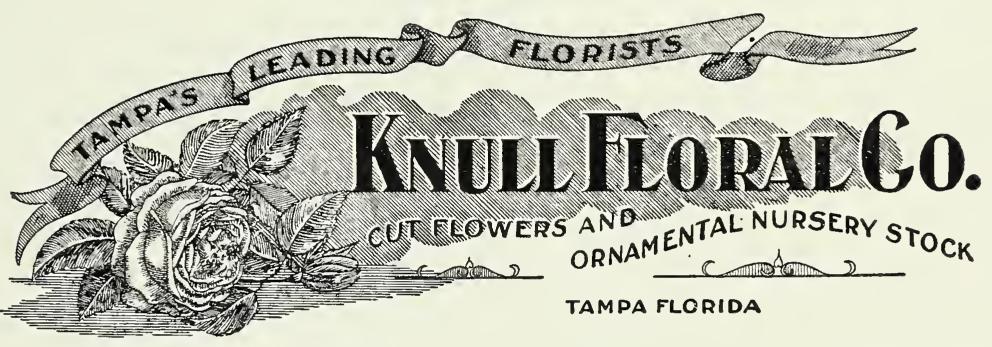

1922 
KNULL FLORAL COMPANT, TAMPA, FLORIDA

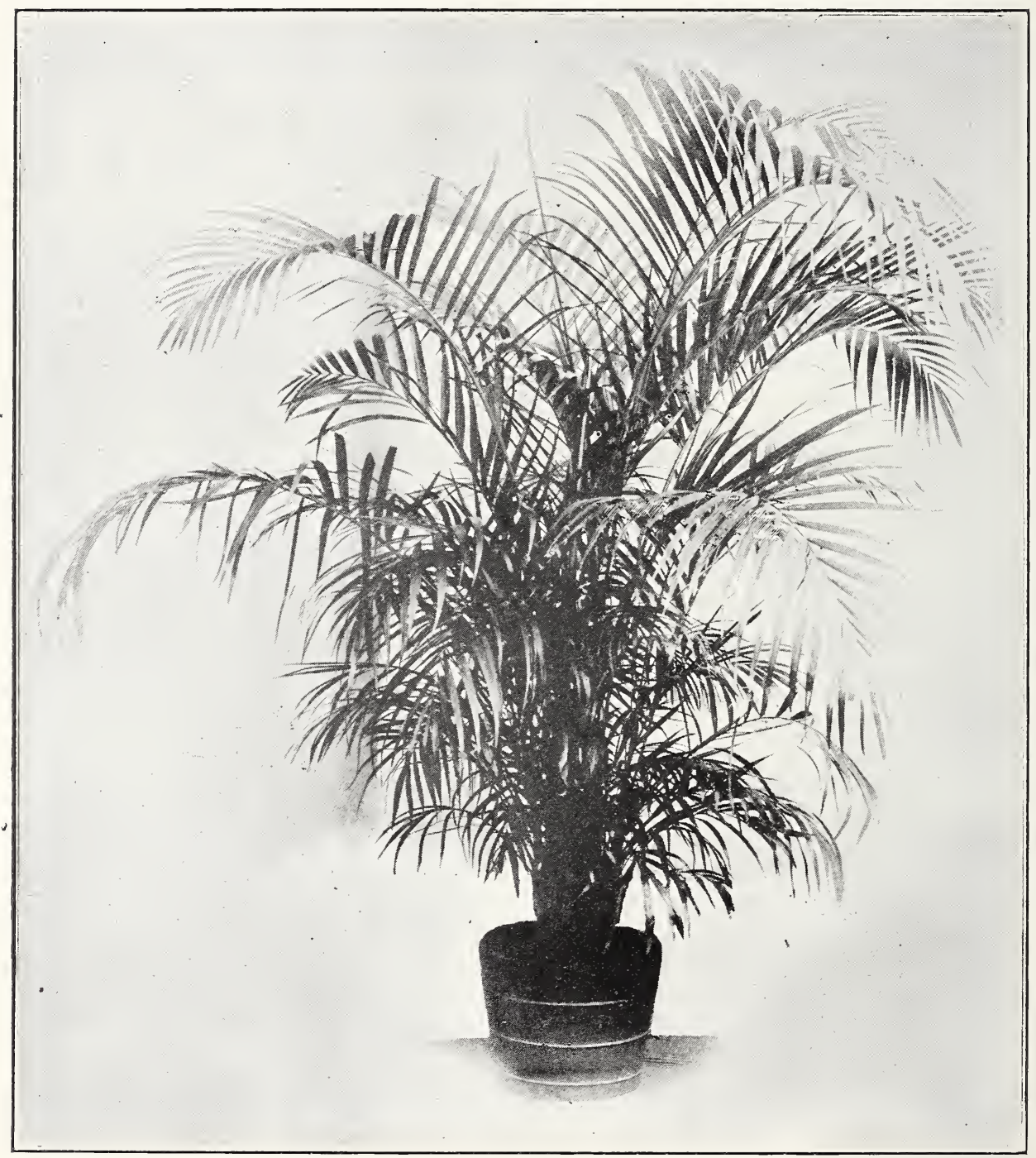

ARECA LUTESCENS 
KNULL FLORAL COMPANY, TAMPA, FLORIDA

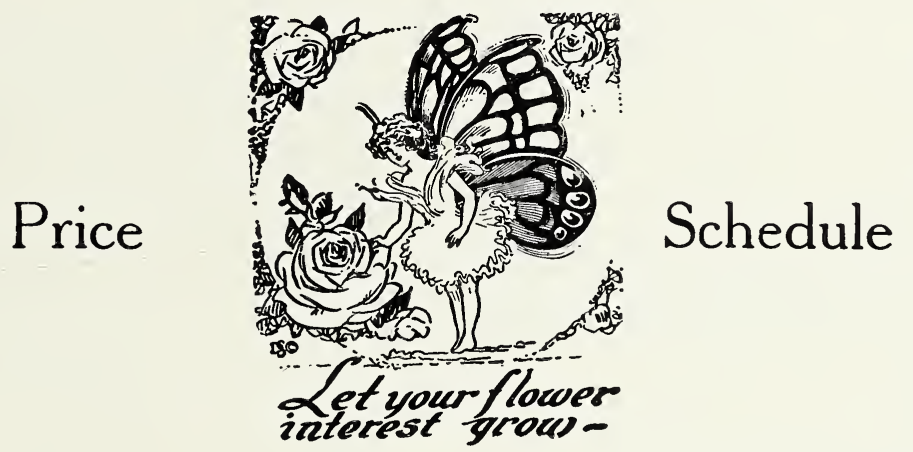

All Plants listed in this Catalogue at

25c. each are $\$ 3.00$ per dozen. $35 \mathrm{c}$. each are 4.00 per dozen.
50c. each are 5.50 per dozen.
(5c. each are 8.25 per dozen.
$\$ 1.00$ each are 11.00 per dozen.

Not less than six at dozen rate.

Bedding Plants are 75 cents per dozen, or $\$ 5.00$ per hundred, except where otherwise stated. Not less than fifty at hundred rate.

\section{Contents}

Bedding Plants

30-32

Coniferous Evergreens

13-14

Ferns

Foliage and Decorative Plants

19-23

Palms

Roses

Seeds

Shade Trees

Shrubs and Flowering Plants

Tuberous, Bulbous and Herbaceous Plants

23-25

Vines and Creepers 


\section{INDEX}

Page

Page

A

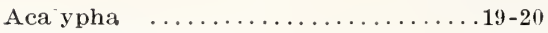

Achyranthes $\ldots \ldots \ldots \ldots \ldots \ldots \ldots \ldots .20$

Adiantum ..................... 29

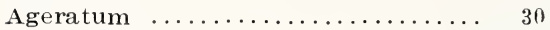

Allamanda .................... 16-27

Alternanther.. .................. 30

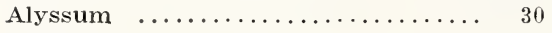

Amarylii $; \ldots \ldots \ldots \ldots \ldots \ldots \ldots \ldots .23$

Amazon L'ly (See L'charis)....... 25

Amoor River Privet (See Ligustrum) 18

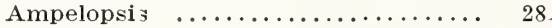

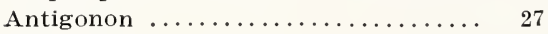

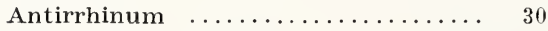

Araucaria ................... 13

Arborvitae (See Thuya)........... 14

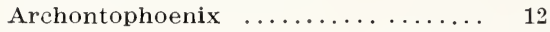

Areca ...................... 12

Asparagus .................. . 29

Aspidistra ................... 20

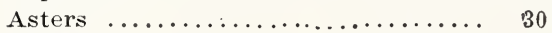

Assonia ..................... 16

Australian Pine (See Casurina).... 13

Australian Silk Oak (See Grevillea). 15

Azalea ..................... 16

\section{B}

Bamboo ....................... 16

Banana Shrub (See Michelia)...... 18

Bauhinia .................... 16

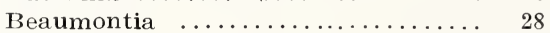

Begonia ..................20-21-23

Bellis Daisy ................. 31

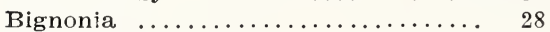

Biota (See Thuya) ............. 14

Boston Fern (See Nephrolepsis)... 29

Boston Ivy (See Ampelopsis) ....... 28

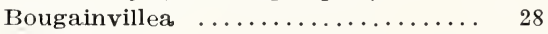

Buddleia ...................... 16

\section{C}

Caesalpina $\ldots \ldots \ldots \ldots \ldots \ldots \ldots \ldots \ldots . \quad 16$

Caladium ................... 23

Calendula ..................... 31

California Fan Palm (See Washing-

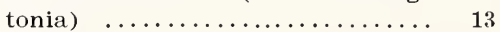

Cal.a Lily ................... 23

Camphor Tree (See Cinnamomum).. 14

Canary Island Date Palm (See

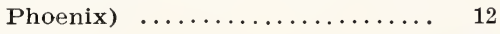

Candytuft ...................... 31

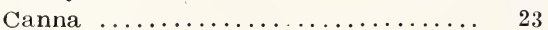

Cape Jasmine (See Gardenia)...... 17

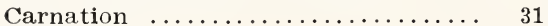

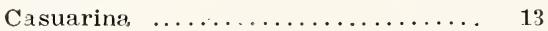

Cestrum ...................... 17

Chamerops (See Trachycarpus).... 13
Chinese Fan Palm (See Latania).... 12

Ch ysanthemum .................. 31

Chrysalidocarpus (See Areca)...... 12

Cinnamomum ................ 14

Clerodendron .................. 28

Climbing Fig (See Ficus)......... 28

Cocos Plumosa ................. 12

Cocos Wedelliana ................ 12

Coleus .......................21-31

Crape Jessamine (See Tabernaemontana) $\ldots \ldots \ldots \ldots \ldots \ldots \ldots \ldots \ldots \ldots$ Crape Myrtle (See Lagerstroemia).. 17 Croton (See Phyllaurea) ........... 22

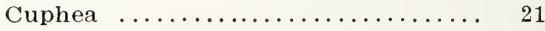

Cupressus .................... 14

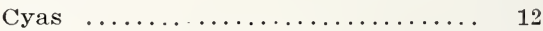

Cyclamen .................. 24

\section{D}

Date Palm (See Phoenix).........12-13

Dahl:a ......................... 31

Daisy ... . . . . . . . . . . . 31

Delonix .................... 14

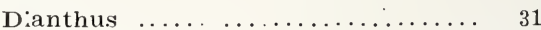

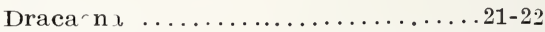

Duranta ..................... 17

Dwarf Poinciana (See Caesalpina).. 16

\section{$\mathbf{E}$}

Easter Lilies.................. 24

English Ivy (See Hedera).......... 28

Eucalyptus .................. 14

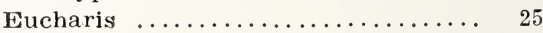

Euphorb:a ................... 17

\section{$\mathbf{F}$}

Ferns $\ldots \ldots \ldots \ldots \ldots \ldots \ldots \ldots \ldots \ldots . \ldots \ldots$

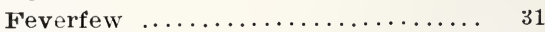

Ficus .................... 14-15-28

Freesias $\ldots \ldots \ldots \ldots \ldots \ldots \ldots \ldots \ldots \ldots, 25$

G

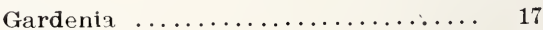

Gelsemium $\ldots \ldots \ldots \ldots \ldots \ldots \ldots \ldots \ldots, 28$

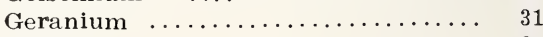

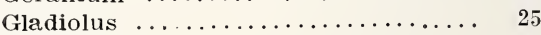

Grevillea .................. 15

\section{H}

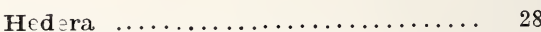

Honeysuckle (See Lonicera......... 28

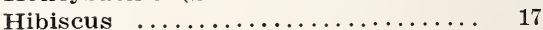

Hydrangea $\ldots \ldots \ldots \ldots \ldots \ldots \ldots \ldots . \ldots \ldots$ 
KNULL FLORAL COMPANY, TAMPA, FLORIDA

\section{INDEX \\ (Continued)}

Page

\section{I}

Ipomea $\ldots \ldots \ldots \ldots \ldots \ldots \ldots \ldots \ldots .28$

Italian Cypress (See Cupressus).... 14

Ivy $\ldots \ldots \ldots \ldots \ldots \ldots \ldots \ldots, 28$

\section{$\mathbf{J}$}

Jacaranda .................... 15

Japanese Hibiscus ............. 18

Jasmine $\ldots \ldots \ldots \ldots \ldots \ldots \ldots \ldots \ldots \ldots \ldots$

Jasminum $\ldots \ldots \ldots \ldots \ldots \ldots \ldots \ldots \ldots \quad 17$

\section{$\mathbf{K}$}

Kentia

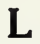

Lace Fern (See Asparagus)......... $\quad 29$

Lagerstroemia ................. 17

Lantana ....................... 18

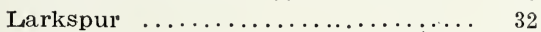

Latania .................... 12

Ligustrum ........................ 18

Lonicera .................. 28

\section{M}

Maiden-Hair Fern (See Adiantum).. $\quad 29$

Malvaviscus ................. 18

Michelia ...................... 18

Moon Vine (See Ipomea).......... 28

Mountain Ebony (See Bauhinia).... 16

\section{$\mathbf{N}$}

Narcissus .................... 25

Nephrolepsis $\ldots \ldots \ldots \ldots \ldots \ldots \ldots \ldots . \ldots 29$

Nerium ................... 19

Night-Biooming Jasmine.......... 17

0

Oleander (See Nerium).

$\mathbf{P}$

Palms .....................12-13

Pandanus ....................

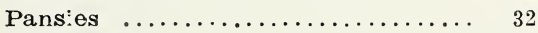

Parkinsonia ..................... 15

Parlor Ivy ................... 28

Petunia ....................... 32

Phoenix .....................12-13

Phyllanthus $\ldots \ldots \ldots \ldots \ldots \ldots \ldots \ldots \ldots . \ldots 2$

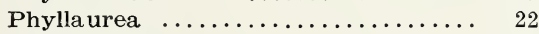

Pittosporum .................... 19

Plumbago .................... 19

Page Five
Poinciana (See Delonix and Caesal-

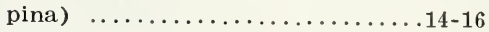
Poinsettia (See Euphorbia)......... 17

Ptyschosperma ................. 13

Pyrostegia (See Bignonia)......... 28

$\mathbf{R}$

Roses ...................25-26-27 Rose Bay (See Tabernaemontana)... 19 Royal Poinciana (See Delonix) ..... 14 Rubber Tree (See Ficus)......... 14

\section{$\mathbf{S}$}

Sago (See Cyas) ................ 12

Salvia ....................... 32

Seaforthia Palm (See Ptyschosperma) ....................... 13 Seeds ........................33-34-35

Shasta (See Daisy)............... 31

Silk Oak (See Grevillea) .......... 15

Snap-dragons (See Antirrhinum).... 30

Solanum ...................... 28

Stag-horn Fern (See Nephrolepsis). 29

Star Jasmine (See Jasmine and Trachelospermum) $\ldots \ldots \ldots \ldots \ldots .28$

Stenolobium .................. 19

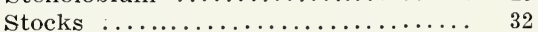

Strobilanthes ................. 19

Swamp Mahogany (See Eucalyptus) 14

\section{$\mathbf{T}$}

Tabernaemontana ................. 19

Table Ferns ................. 29

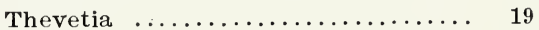

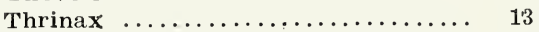

Thuya ......................... 14

Thunbergia .................... $19-28$

Trachelospermum ................. 28

Trachycarpus .................... 13

Tradescantia ................... 23

Trumpet Flower (See Thevetia) ... 19

\section{V}

Verbena $\ldots \ldots \ldots \ldots \ldots \ldots \ldots \ldots \ldots . \quad 32$

Violets ................... 32

\section{W}

Wandering Jew (See Tradescantia). 23

Washingtonia ................ 13

\section{Y}

Yellow Elder (See Stenolobium).... 28

Yellow Jasmine (See Gelsemium)... 28

\section{$\mathbf{Z}$}

Zinnia $\ldots \ldots \ldots \ldots \ldots \ldots \ldots \ldots \ldots \ldots,{ }_{32}$ 


\section{KNULL FLORAL CO. ESTABLISHED IN 1909.}

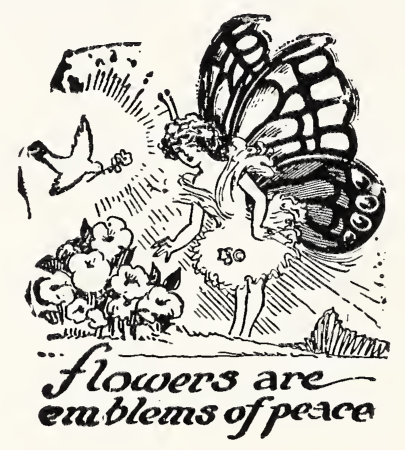

We are now entering the thirteenth year of continued business in serving critical buyers of plants, seeds, bulbs and eutflowers. We feel that our efforts to please have been amply rewarded as from a small beginning we have now grown to be the largest concern of the kind in the Lower South.

We do not base our claim for your support merely on the fact that we have been established for this length of time, but rather to the fact that we are at all times alive to the wants of our customers and try to keep abreast of the times in floral matters. It has always been our aim to give satisfaction to our customers, and no matter how small the order may be it receives the same careful attention we give the larger orders.

We wish to thank our customers for their generous patronage of the past and assure them that we will continue to do all in our power to merit the continuance of their confidence.

Nearly all our plants are pot-grown and may be moved at any time of year. Let us urge you to send in your order as soon as you can and say at just what date you want the plants sent; in doing this some delay will be avoided in busy seasons, when orders are filled strictly in turn and delay is unavoidable.

Let us know your needs. OUR LANDSCAPE SERVICE stands ready at all times to assist you in making the proper selections to beautify your home grounds, parks and cities.

Yours for faithful service,

\section{KNULL FLORAL COMPANY,}

TAMPA, FLORIDA 


\section{Business Information}

TERMS-Cash with order. Send remittances in full to cover order, postage and packing charges. We do not ship plants C. O. D.

REMITTANCES should be made by Post-Office or Express Money Order, Registered Letter or Bank Draft.

MINIMUM ORDERS - We do not eare to ship orders amounting to less than $\$ 1.00$.

NON-WARRANTY - Most failures of plants are due to causes beyond our control, such as unfavorable weather or soil conditions, too deep or too shallow planting, lack of water, etc., which renders it impossible for us to guarantee success. We exercise the utmost eare in keeping our stock labeled true to name and send out only such stock as we feel positive are so marked.

LOCAL DELIVERIES - We deliver, free, to all parts of the city inside the corporation line and to all transportation companies.

PACKING - All plants are packed free, except when for export. As such orders require special packing material, which at the present time has greatly increased in cost, we are obliged to make a charge for this extra packing, but only the actual cost of material used is charged, which amounts to about $5 \%$.

SAFE ARRIVAL - While exercising every precaution in packing, etc., we cannot stand responsible for safe and prompt delivery of goods. Our responsibility ceases on delivery in good condition to Transportation Company, however, we will be glad to assist in collecting damages in transportation. Such claims should be properly filed with Transportation Company and immediately notify us that we may render all assistance possible. All claims must be made on receipt of goods.

SHIPPING BY MAIL - When ordering plants for shipment by mail add 25 per cent to catalogue price to cover packing and postage. On all long shipments we would strongly advise shipping via express, as it is not only cheapest, but best, as plants can be better packed.

CORRESPONDENCE - Address all communications concerning plants, bulbs, etc., to "Plant Department," 408 Tampa Street. We give prompt attention to all letters of inquiry. All we ask is that you state questions clearly and be very sure your name and address are written plainly. 
KNULL FLORAL COMPANY, TAMPA, FLORIDA
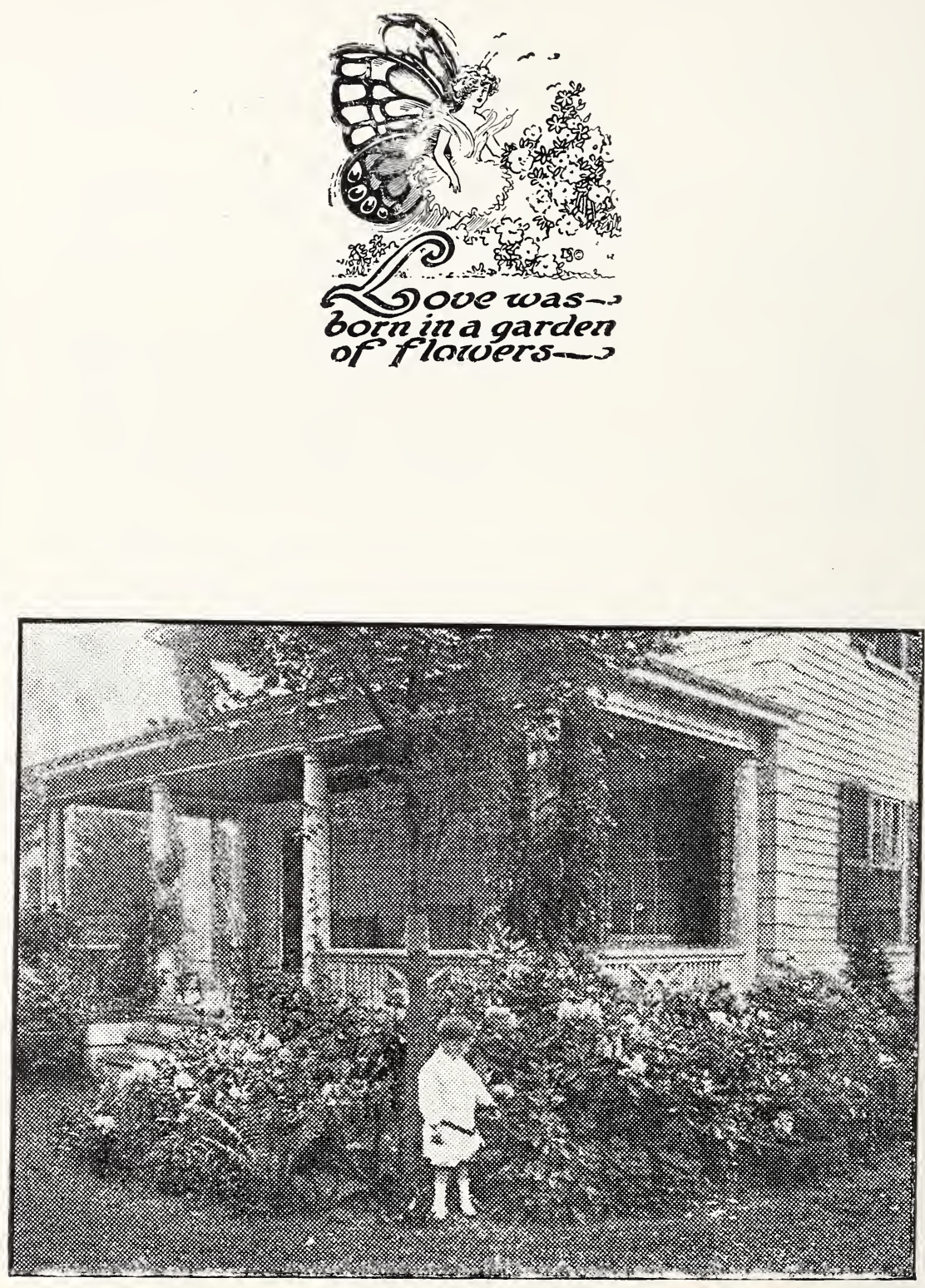

A PLEASING ARRANGEMENT OF PLANTS FOR THE AVERAGE HOME 


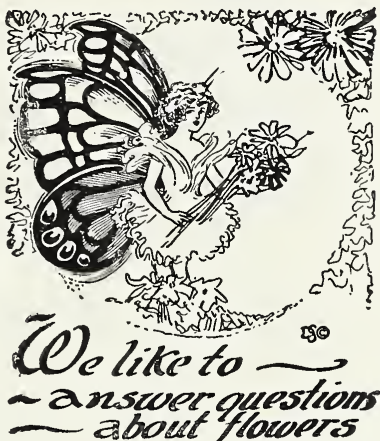

\section{Department of Landscape Service.}

With the large and varied supply of nursery stock that we now have at our command we are prepared to take entire charge of Landscaping your grounds. We will be glad to call and inspect same, in order that we may be better able to understand the particular requirements of your location, as every place has its own problems to be worked out, which are different from all others.

Out-of-town customers may sketch their property on a sheet of paper ruled into squares, allowing 20 feet to the inch. Note on this sketch house, garage, drives, walks, fences, outbuildings, any trees, shrubbery or other permanent things that are not to be removed. Also location of all entrances to lot and buildings, any terraces or grades of any importance, direction from house of chief views, both the desirable and objectionable ones, if any. Direction house faces: North, East, South or West should be given. A photograph showing buildings or grounds would be a great help to us and will, if desired, be returned to you.

We have made a special study of planting small city lots, and with our large experience in the planting of such places, we feel that we could be of great service to you in planning your home grounds. On receipt of sketch and $\$ 5.00$, for which we will mail you a credit memo. to be applied on an order for plants amounting to $\$ 25.00$ or more, providing order is received at our office within thirty days from date of credit memo, we will submit pencil drawing for proper planting of your grounds. This drawing will enable you to plant the entire grounds at one time, or only a few things at a time and accomplish the same result in the end as though planted all at once. Luxurious grounds may be obtained by this method with the outlay of but a few dollars at any one time.

Let us help you solve your particular problem. If you are in any way interetsed in Landscape work confer with us first before taking definite steps.

$$
\begin{aligned}
& \text { KNULL FLORAL COMPANY, } \\
& \text { Department of Landscape Service. }
\end{aligned}
$$




\section{Notes on}

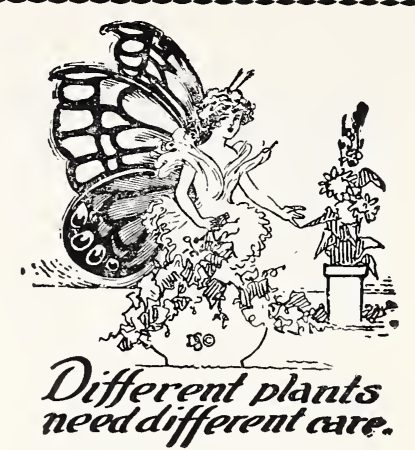

\section{Planting}

After first clearing the ground of all grass, weeds, etc., cover space to be planted with a good thick layer of well-rotted cowmanure or any good commercial fertilizer. If humus is available it may be profitably added, especially to the commercial fertilizer. Then spade deep, being careful to thoroughly mix through the soil. Providing land is newly cleared and sour it should have a coating of lime, then be spaded up and let lay a few days or weeks to sweeten in the air and sunlight before planting.

ARRIVAL OF PLANTS-Remove plants from box and take off covering from foliage, placing them in a shady place in an upright position. Care should be used to keep roots well covered to exclude air and sprinkle well. They may, when necessary, be held safely in this manner for several days.

SETTING-After the soil has been prepared as above make a hole large enough to receive the plant without molesting the roots and plant only slightly deeper than they were in the pot. Plants from open ground should have the hole large enough to receive the roots opened out in natural position and planted about an inch deeper than before. After placing plant in desired position fill the hole about three-quarters full of soil, then pour in water enough to nearly fill the hole. As soon as this water soaks in fill up with soil and pack well by tramping with the feet. Soil that has not been previously prepared may be successfully planted as above, then mulched with well-rotted cow-manure or commercial fertilizer, being careful to keep the fertilizer a few inches away from the body of the plants. Watering and rains will then dissolve and carry the fertilizer down to the roots of the plants. This, we consider, the safest method for amateur planters as there is little chance of the plants getting burned by too strong fertilizer. Never let them lack for water until well established.

WATERING-Watering potted plants is very important and must be governed to a great extent by ones own judgment. When watering use enough so water will pass down through and out the bottom of the pots freely. Potted plants and hanging baskets will be greatly improved if placed in a bucket or tub of water for about fifteen minutes every week or ten days. This method will insure all the soil and center of the roots getting thoroughly saturated. 


\section{Palms.}

The Palm is the most beautiful of all plants for out-door southern planting and should have a larger part in making the home grounds, parks and streets more beautiful, adding that tropical and elegant display that nothing else can equal. As a small ornamental plant to adorn the living room, there is nothing that compares with the palm, either in beauty or hardiness.

Group planting on large grounds give the most beautiful and striking effect, but on smaller grounds single planting is more effective.

Plant the palms without in any way distrubing the soil that comes about their roots, using plenty! of water and pack it tightly into place. After planting, the tops should be kept tied up for a few weeks to keep them from tossing about in the wind, thereby loosening the plant in the soil. Water freely and when new growth starts fertilize with well-rotted stable manure. Palms are gross feeders and, when possible, they should be given an abundance of fertilizer, moisture and cultivation during the spring and summer, but suspend cultivation and fertilizer in the fall to give them opportunity to harden up for the winter. Any good commercial fertilizer may be used, but cautiously, to avoid burning. Rich soil should be used in potted palms and drainage must be perfect. House palms require some sunshine and thrive best with morning and afternoon sunlight, avoiding the midday heat.

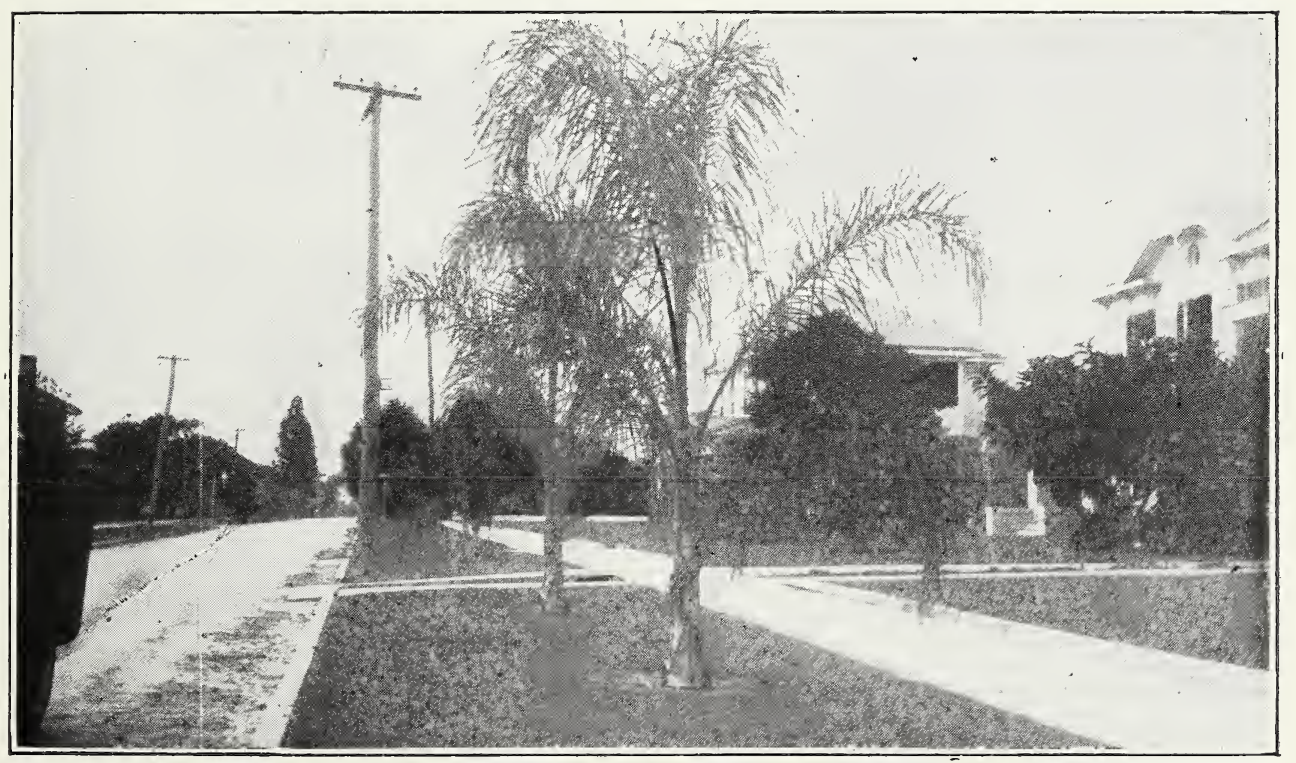

\section{COCOS PLUMOSA}

This is one of the very best Palms for outdoor planting in Florida, grows rapidly, is tall, graceful, and forms a good sized trunk. Very similar to the Royal Palm, only it is hardy in this section. 


\section{PALMS - Continued}

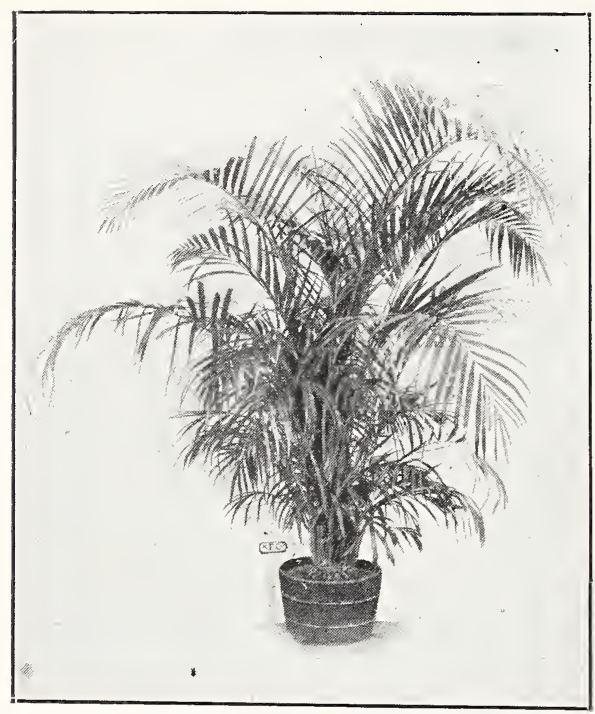

ARECA LUTESCENS

A R E C A lutescens (Chrysalidocarpus lutescens) - One of the most beautiful of all palms for house decoration. Its pinnate leaves are glossy green and gracefully arched on slender yellow stems. Many offshoots develop from the base, $75 \mathrm{c}$ to $\$ 3$. Tub specimen plants, $\$ 8$ to $\$ 25$.

\section{ARCHONTOPHOENIX alexandrae.-} Tall, showy, elegant palm with smooth, stout trunk growing 50 to 80 feet tall, conspicuously ringed from leaf scars. Resembles the Seaforthea. $\$ 10.00$ and $\$ 12.00$.

cocos plumosa-One of the finest for outdoor planting in South Florida, somewhat resembles the Royal Palm. The smooth trunk, about 12 inches thick, reaches a height of 35 feet or more, crowned with dark-green leaves, often 15 feet in length, make a very striking picture. It is a very rapid grower. Small plants, 25c, 35c, and 50c; large plants $\$ 3.00$ to $\$ 6.00$.

cocos wedelliana-A beautiful dwarf palm suitable, while young, for small jardinieres or fern dishes. $35 \mathrm{c}$ and $50 \mathrm{c}$.

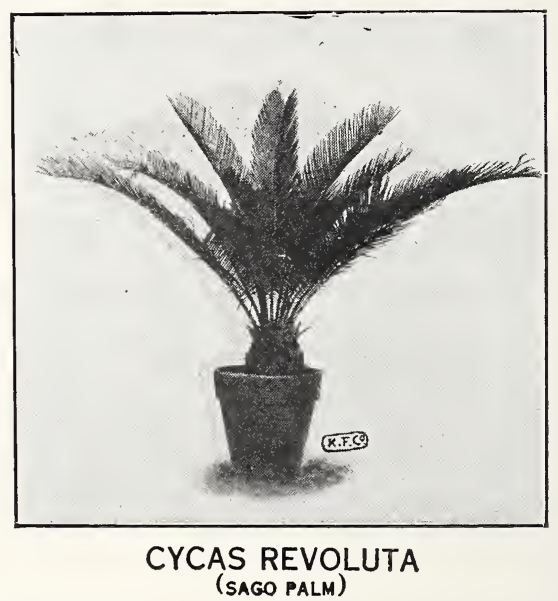

CYAS revoluta (Sago Palm)-A beautiful plant resembling a palm, with a handsome dense crown of symmetrical deepgreen pinnate leaves curving outward from the center. Quite hardy in Florida and the Gulf States. It requires very little attention after being planted a few months. If used for a house plant, give it a very sunny exposure while it is making its rapid growth, which is during the spring and eariy summer. 25c to $\$ 3.00$.

KENTIA belmoreana-This is one of the best palms for use as window, table or conservatory decorations. Rather dwarf with dark-green pinnate leaves arching gracefully. $35 \mathrm{c}, 50 \mathrm{c}$; made up $75 \mathrm{c}$ to $\$ 2.00$.

LATANIA borbonica (Chinese Fan Palm) - A hardy, rather slow-growing palm with large fan-shaped leaves. Very ornamental and is well adapted for either indoor or outdoor decorative purposes. $\$ 1.00, \$ 1.50$ and $\$ 2.00$. Specimens $\$ 3.00$ to $\$ 5.00$.

Phoenix canariensis (Canary Island Date)-We recommend this type as one of the hardiest and especially fite for lawn or avenue planting. It is one of the most beautiful with its long dark green leaves and massive trunk, and makes very rapid growth when planted in rich moist soil. $50 \mathrm{c}, 75 \mathrm{c}$ and $\$ 1.00$; strong plants $\$ 3.00$ to $\$ 5.00$. 


\section{PALMS - Continued}

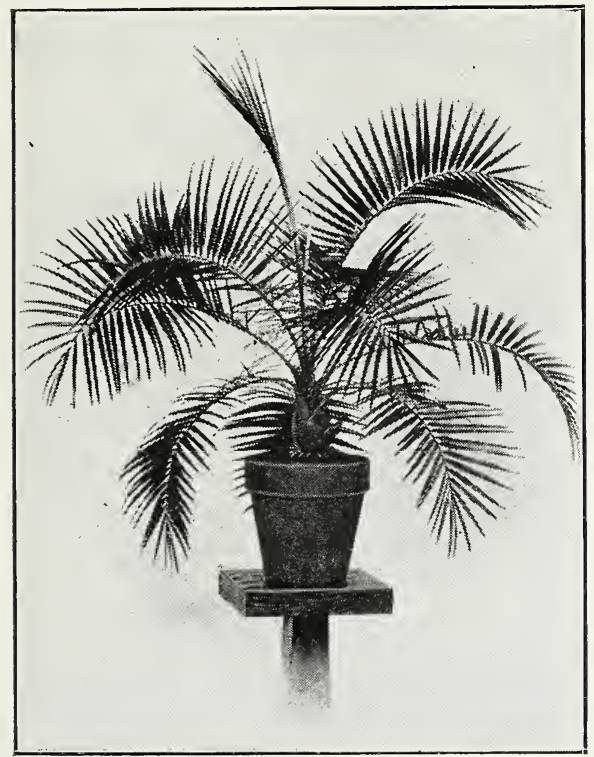

PH. RECLINATA

Ph. Reclinata - A very showy palm with beautiful arching dark green leaves. It grows very rapidly and produces numerous suckers from the base which, if allowed to grow, develop into immense clumps. It makes a tree suitable for street planting if small suckers are removed for a few years, after which they will cease to sprout out, but it is better to let it take its natural course, as after being trimmed its tall, slender trunk is usually crooked and not very attractive. It is very valuable for use in landscape work and if intended for an individual specimen should have plenty of room. $50 \mathrm{c}, 75 \mathrm{c}$ and $\$ 1.00$. Specimens in tubs $\$ 5.00$ to $\$ 8.00$.

P TYCHOSPERM A elegans (Seaforthia)-A very graceful slender palm with dark green pinnate leaves up to $\mathbf{1 0}$ feet long. Fine for decorative purposes. Small plants $35 \mathrm{c}$ and $50 \mathrm{c}$; strong plants in tubs $\$ 3.00$ to $\$ 5.00$.
TRACHYCARPUS fort un e i (Chamerops)-A dwarf fan with leaves finely divided into many segments. Slow grower, but very hardy. Strong tub plants $\$ 3.00$ to $\$ 5.00$.

THRINAX wendlandiana - This palm has deeply cleft fan-shaped leaves from 1 to 2 feet long and reaches a height of from 10 to 12 feet. $\$ 1.50$ to $\$ 3.50$; tub specimen $\$ 20.00$

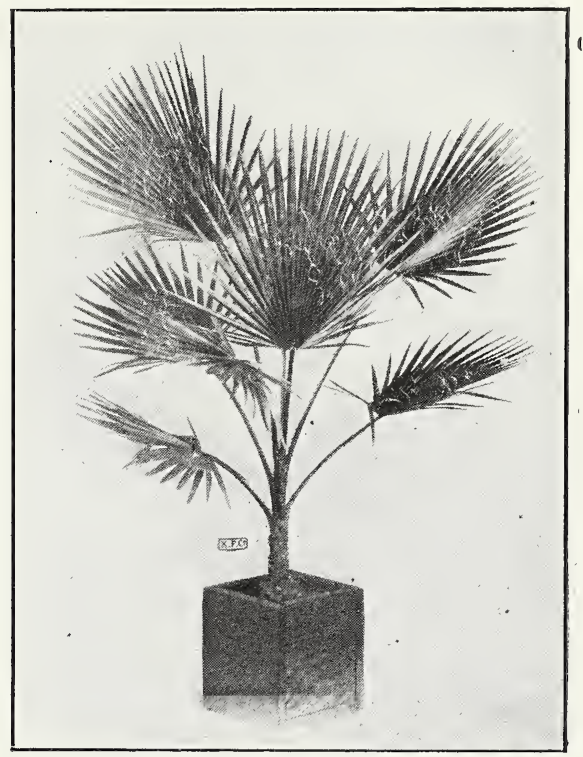

\section{WASHINGTON ROBUSTA}

(SILK THREAD PALM)

WASHINGTONIA robusta (California Fan Palm)-Hardy, quick growing palm, well adapted to Florida and the Gulf States. Its very massive trunk is crowned with giant fan-shaped leaves, which are furnished with white threads, giving it the common name of "Thread Palm." $35 \mathrm{c}$ and $50 \mathrm{c}$; strong plants $\$ 2.00$ to $\$ 4.00$; specimen plants in tubs $\$ 5.00$.

\section{Coniferous Evergreens}

These plants, when in tubs, are very satisfactory for porches or steps, also make beautiful individual specimens for lawns. They make excellent background for other shrubs and can be used in groupings or for hedges. They are hardy and long lived.

ARAUCARIA bidwelli (Monkey Puzzle)-A beautiful tree of symmetrical growth with stiff pointed leaves. Branches from ground up and reaches an enormous size. Does well in South Florida, standing severe frost. $\$ 2.50$ to $\$ 3.50$.
CASUARINA equisetifolia (Australian Pine)-A very striking slender branched tree used in South Florida and California as avenue trees and wind breaks. $35 \mathrm{c}$ and $75 \mathrm{c}$. 


\section{CONIFEROUS EVERGREENS - Continued}

CUPRESSUS sempervirens (Italian Cypress)-Very tall and stately with slender branches lying close to the stem. Especially fine for landscape work and cemetery planting. Grows to a height of 75 feet. $50 \mathrm{c}$ to $\$ 3.50$.

THUYA aurea nana-The best golden dwarf arborvitae. Compact rounded head and handsome greenish golden foliage.
Very popular for window boxes and urns, also fine for cemetery or general planting in many ways. $\$ 2.50$ and $\$ 3.00$; large specimen plants $\$ 10.00$.

T. orientalis aurea pyramidalis - An erect, compact grower of beautiful golden tint, reaching a height of about 15 feet. $25 \mathrm{c}$ to $\$ 3.50$.

\section{Shade Trees}

Nothing is more essential to a home than shade trees. Well planted healthy shade trees add attractiveness to any town or city streets and parks. They should be given first consideration in planting on home grounds, not only serving as a background for the home, but often concealing out buildings or unsightly views that should be screened.

Pot-grown trees may be planted at any time as their roots are disturbed but little; the open-ground trees should be set during the winter months, when they are dormant.

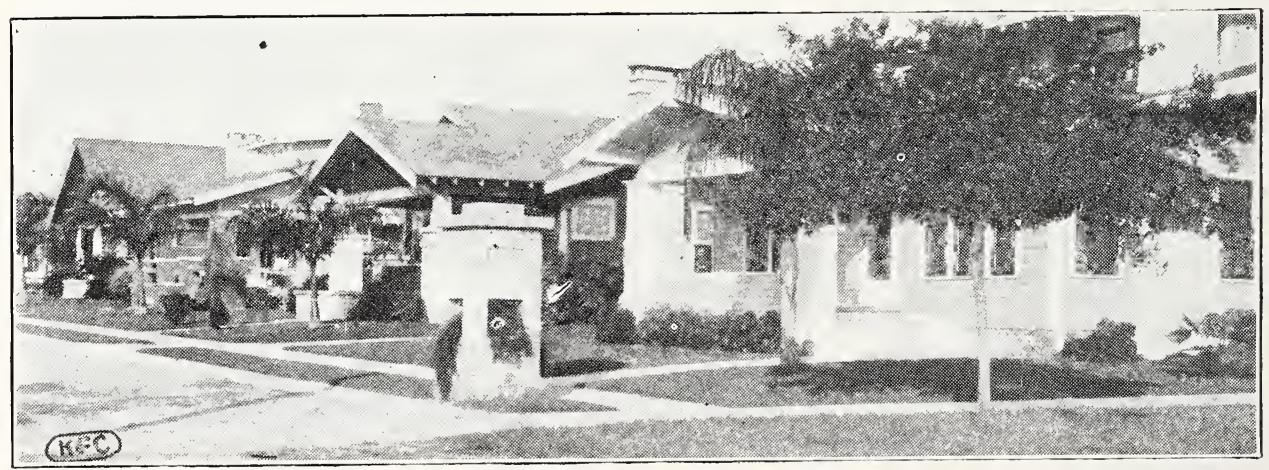

BAUHINIA (Mounta:n Ebony or Bohemian Shrub) - See SHRUBS.

CINNAMOMUM camphora (Camphor Tree)-A handsome tree, very dense at top, with wide spreading branches. Can be used as shade trees or trimmed to any size for hedges or wind breaks. Hardy throughout Florida. 50c to $\$ 2.50$.

DELONIX regia (Royal Poinciana)One of the most striking and beautiful of tropical trees. Very rapid grower, with wide spreading umbrella-shaped top bearing bright scarlet flowers, often 3 to 4 inches across, during spring and early summer. $\$ 1.00$ and $\$ 1.50$.

EUCALYPTUS polyanthemos-A very ornamental variety with leaves nearly round and silvery. Thrives under a great variety of climatic conditions. $25 \mathrm{c}$ to $\$ 1.00$.

E. robusta (Swamp Mahogany)-Unusually fine as a shade tree with its broad leaves and spreading habits. Very rapid growing and most desirable Eucalyptus for shade. $25 \mathrm{c}$ to $\$ 1.00$.

E. rudis-Very fine for street planting; stands drouth better than most varieties. Young growth is deep copper color. 25c to $\$ 1.00$.

FICUS altissima (Rubber Tree)-A very tall, vigorous tree, with large, thick loundish leaves beautifully veined. A fine quick growing shade tree for extreme South Florida and the Tropics. $50 \mathrm{c}, \$ 1.00$ and $\$ 1.50$.

F. elastica (India Rubber Tree)-The most common of all rubber trees. Grows to immense size, reaching a height of 100 feet in the tropics. The leaves are very dark, glossy green and leathery, growing to 12 inches in length. It is of very easy culture and, because of its handsome appearance, should be much used in interior decorative work. Very rapid grower. $50 \mathrm{c}, \$ 1.00$ and $\$ 1.50$. 
KNULL FLORAL COMPAN T, TA MPA, FLORIDA

\section{SHADE TREES - Continued}

F. elastica variegata-Similar to Elastica. Leaves are creamy white and bright green. $\$ 1.00$ to $\$ 2.00$.

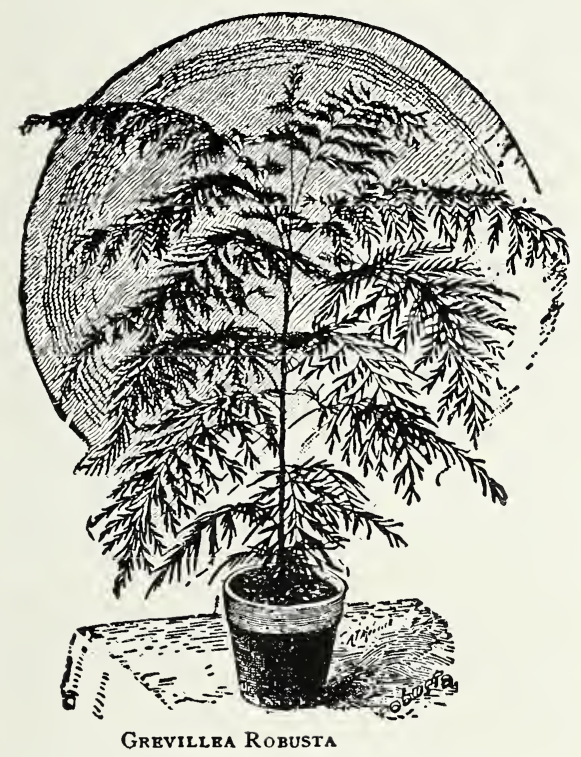

F. pandurata majestica (Carnero)The odd construction and mammoth leaves of this new decorative plant make a very striking appearance. The leaves are guitar-shaped with the larger end out, stiffly uprising from the central stalk. They are very thick and rubbery, 10 inches wide by 15 inches long; dark green, with creamy white veins which on under side are purple and boldly projecting. $\$ 1.00$ to $\$ 3.00$. Tub specimens $\$ 15.00$.

GREVILLEA robusta (Australian Silk Oak)-A tall beautiful shade tree with fern-like leaves. Grows rapidly, reaching a height of 120 feet, but by cutting out the top when it has reached a good size makes a fine spreading tree. It is evergreen and well adapted to growing as street or lawn trees in South Florida. Has quantities of deep yellow flowers in spring. Fine for decorations when small. $35 \mathrm{c}$ to $\$ 1.00$.

JACARANDA mimosaefolia - One of the loveliest trees for South Florida planting. The foliage is very finely cut, almost fern-like. Beautiful lavender-blue flowers are borne in great abundance in May. $\$ 1.00$ and $\$ 1.50$.

PARKINSONIA aculeata (Jerusalem Thorn)-A small thorny tree growing to a height of about 20 feet. Branches, pendulous and bearing long narrow, feathery leaves. It is a mass of bright, yellow flowers in late spring. $75 \mathrm{c}$ to $\$ 1.50$.

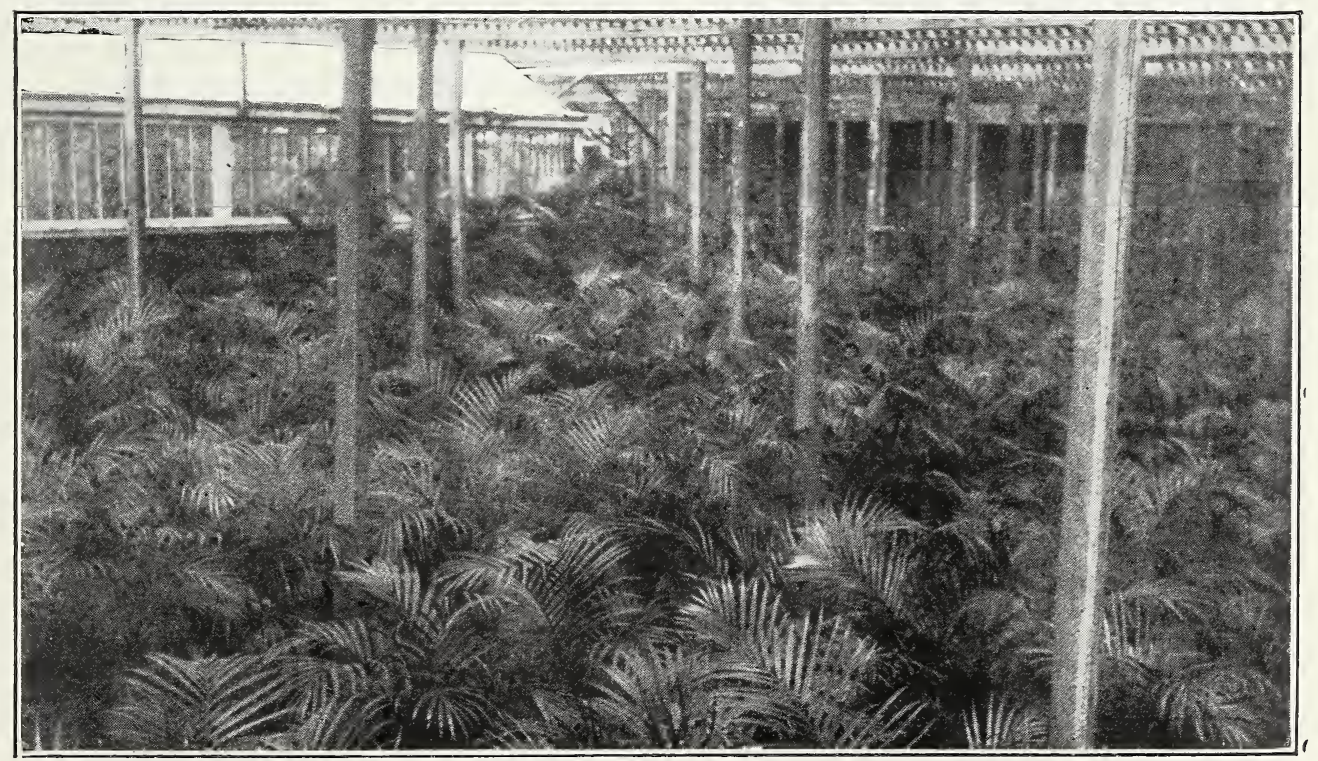




\section{Shrubs and Flowering Plants}

ACALYPHA-See foliage and decorative plants.

ALLAMANDA hendersoni-This plant may be trained either as a vine or shrub. Tender, but spring weather will soon remedy any damage frosts may have cone. Large glossy green leaves, trumpet-shaped golden yellow flowers from 4 to 5 inches produced freely the entire year. $35 \mathrm{c}, 50 \mathrm{c}$ and $\$ 1.00$.

ASSONIA wallichii - This makes a large shrub or small tree up to 30 feet high, with large, velvety leaves and lovcly pink flowers in large, compact, drooping bunches in winter. A very showy plant when in bloom. Especially fine for the big open border where it can have plenty of room to develop. $35 \mathrm{c}$ to $\$ 1.00$.

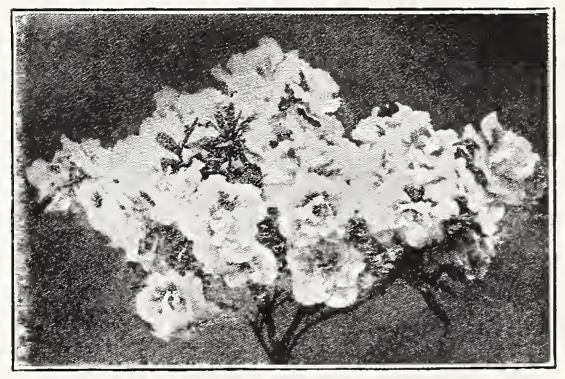

AZALEA INDICA

AZALEA ind ca (Indian Azaleas)These beautiful shrubs are perfectly hardy as far north as Central Georgia. They require a somewhat shady situation where they are protected from the hot afternoon sun of summer. The best soil is one containing an abundance of leaf mold, peat and sand, but soil should be well drained. Should be kept well mulched with rotted leaves, preferably leaves of hardwood trees. If plants are kept growing in pots they should be repotted after flowering and before the new growth begins. Keep the plants sheltered a few days and then plunge the pots in the open ground in a shady place, or they may be planted in an open border and kept shaded. Nothing is more pleasing than Azaleas planted in masses of solid or well contrasting colors. Water should always be furnished abundantly. We offer, in varieties with single flowers, scarlet, salmon, white and purple and white only, in the double flowering. $\$ 2.50$ to $\$ 4.00$.
BAMBOOS-None of the ornamental plants are more important than the Bamboo where tropical effects are desired. The long willowy canes and fine fo'iage give a very pleasing cffect. It is not only valuable for i's scenic efiect, but is excellent for wind breaks, for hedges and as screens for unsightly buildings or other objects. They do well on a wide range of soils, if on very poor soil either stable manure or commercial fertilizer may be used to good advantage. In ditches, canals and water courses they grow to perfection.

B. argentea-A fine Japanese specie, very tall, reaching a poss:ble height of 35 or 40 fest. It makes thick clumps and the shoots, bearing small foliage, bend outward very gracefully. Quite hardy and does well in any soil. From pots 25c; clumps $35 \mathrm{c}$ to $\$ 5.00$.

B. argentea striata-Like Argentea, except foliage, is striped with white, which is especially noticeable during rapid growth. A strong grower. Hardy. From pots $25 \mathrm{c}$; clumps $35 \mathrm{c}$ to $\$ 5.00$.

B. disticha-Rather dwarf bamboo reaching a height of 10 feet and forming dense clumps. Foliage small and narrow. 12 inches across, are very brilliant and attractive, remaining vivid for many weeks. Young stock 25c; heavy plants $50 \mathrm{c}$ and $75 \mathrm{c}$; made-up tubs $\$ 2.00$ to $\$ 5.00$.

BAUHINIA purpurea triandra (Mountain Ebony) - One of the most showy flowering shrubs or small trees, is very attrac ${ }^{\prime}$ ive with its odd twin leaves which lose at night. Large, fragrant, orchidlike flowers are produced freely in early spring. $50 \mathrm{c}$ to $\$ 1.00$.

BUDDLEIA veribilis magnifica (Butterfly Bush or Summer Lilac)-The Buddleia is a magnificent new shrub. It is perfectly hardy and thrives in all sorts of soils, grows vigorously from two to three feet high and blooms the first season from spring planting. Long spikes of fragrant, lilac-colored flowers, often 10 inches in length by 3 inches in diameter, are borne in great profusion throughout the summer and fall. In the spring the old plants should be cut back to the ground and they will throw up a fresh, strong growth. Very rapid grower. In South Florida plant in autumn for winter flowering. $35 \mathrm{c}$ and $50 \mathrm{c}$.

C A ES A L P INA pulcherrima (Dwarf Poinciana)-One of the most popular shrubs, growing from 6 to 10 feet high, 


\section{SHRUBS AND FLOWERING PLANTS - Continued}

with rather small pinnate leaves. Very showy with its bright red and yellow flowers, which are borne in great terminal clusters during the larger part of the year. Young stock 25c and $35 \mathrm{c}$; large plants $\$ 1.00$ and $\$ 1.50$.

CESTRUM nocturnum (Night-blooming Jessamine)-A large rank-growing shrub with flowers greenish in color, opening about sundown and emitting a very heavy fragrance. Blooms at intervals throughout the year. $35 \mathrm{c}$ to $\$ 1.00$.

DURANTA plumieri (Golden Dewdrop) A very attractive shrub reaching 10 to 15 feet. Delicate lilac flowers are borne in great profusion followed by yellow fruits hanging like small pendant golden balls. This is good for hedges or as a single specimen plant. $35 \mathrm{c}$ to $\$ 1.00$.

EUPHORBIA pulcherrima (The Poinsettia)-A well-known plant which is especially popular as a Xmas pot plant. Can be grown in the open in warm countries. The great scarlet bracts, from 6 to 12 inches across, are very brilliant and attractive, remaining vivid for many weeks. Young stock 25c; heavy plants 50 and $75 \mathrm{c}$. Made up tubs $\$ 2.00$ to $\$ 5.00$.

White Poinsettia-This is like the common Poinsettia, except the bracts are white. $50 \mathrm{c}, 75 \mathrm{c}$ and $\$ 1.00$.

GARDENIA (Cape Jasmine)-This is a very popular evergreen shrub with bright glossy foliage and large, fragrant white flowers freely produced from May until fall. From pots $35 \mathrm{c}$ and $50 \mathrm{c}$.

HIBISCUS rosa-sinensis (Chinese $\mathrm{Hi}$ biscus)-One of the finest and most satisfactory shrubs for Florida planting. May be planted single or in groups and does exceedingly well as a hedge, standing clipping well. In the North they can be grown as a house plant, if kept in a warm sunny window during the winter, and will bloom profusely, making a fine decorative plant, but during the summer, if planted in open ground, they make a gorgeous display with their enormous bright colored flowers. $35 \mathrm{c}, 50 \mathrm{c}$ and $75 \mathrm{c}$; tub specimens, write for prices.

H. double pink (American Beauty)One of the best. Very double rich car. mine pink flowers.

H. double scarlet-Very attractive with its deep scarlet colored flowers. Not so strong a grower as the single varieties, but a very free bloomer.

H. peachblow-A very beautiful variety and a vigorous grower. Flowers are large, double and salmon-pink color with darker centers.

H. schizopetalus (Climbing Hibiscus)Small, gracefully drooping, single flowers of a pinkish red color with petals peculiarly cut and twisted.

H. single pink-Flowers are pink and of large size, usually 4 to 5 inches across.

H. single scarlet-This variety is very popular with its glittering scarlet flowers which are borne throughout the entire year.

H. single orange-This variety makes a very large bush and is very attractive with its delicate orange flowers with red throats. Free bloomer.

H. thalia-Single crepe-like pink flowers with reddish centers.

H. white wings-A choice single Hibis. cus with flowers opening pink, but rapidly fading to white.

HYDRANGEA (Hortensia)-Nothing is more attractive than a mass of well developed Hydrangeas. They are very vigorous, healthy and rapid growers, generally hardy in the South. Bear immense heads of flowers varying from white to blue and pink, according to the soil in which they are grown. We cannot guarantee the colors in different localities. Blue is a color that is not fixed in $\mathrm{Hy}$ drangeas. It is controlled entirely by soil conditions. They thrive best under partial shade and require a liberal supply of water during their season of growth and flowering. 35c, 50c and 75c; tub specimen plants $\$ 1.00$ to $\$ 5.00$.

H. otaksa-An old favorite used exten. sively as a potted plant at Easter. Produces large clusters of flowers, pink or blue, according to the soil. Strong grower, and one of the most satisfactory for out-door planting in South Florida.

H. Maurice Hamar-Delicate flesh-rose color, in some soils a beautiful deep blue.

H. Thomas Hogg - A very desirable variety with immense trusses of pure white flowers.

JASMINUM sambac (Grand Duke)-A fragrant Jessamine with dark green glossy foliage and very double, white, waxy flowers. $35 \mathrm{c}$ and $50 \mathrm{c}$; heavy stock $\$ 1.00$.

J. sambac (Maid of Orleans) - Very fragrant semi-double white flowers continualy in bloom. $35 \mathrm{c}$ and $50 \mathrm{c}$; heavy stock $\$ 1.00$.

LAGERSTROEMIA indica (Crepe Myrtle) - One of the most beautiful 


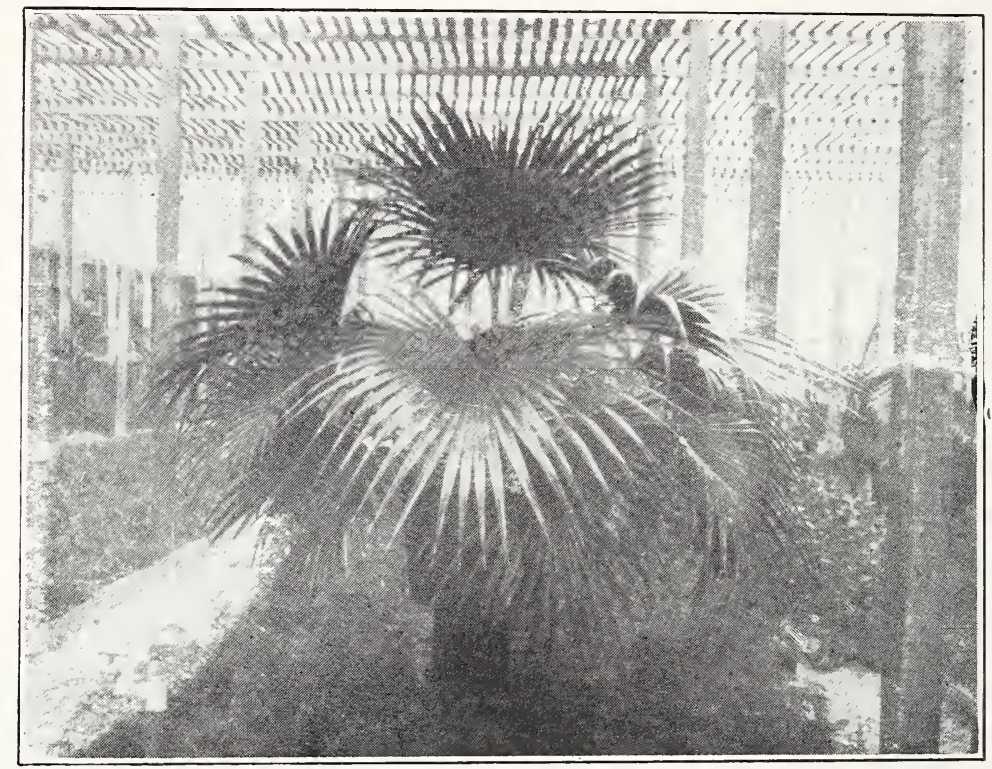

\section{LATANIA---BORBONICA}

shrubs or small trees, reaching a height of 15 to 20 feet. They are hardy and easily grown. The masses of flowers which appear in great abundance throughout the summer are beautifully fringed and borne in large clusters. Very desirable as a hedge plant, single specimen or when in mass planting makes a most striking effect. $35 \mathrm{c}$ and $50 \mathrm{c}$; heavy stock $\$ 1.00$.

L. alba perfecta-A very free flowering variety bearing large clusters of pure white crepe-like flowers.

L. carmine-Very bright colored flowers.

L. pink-The most common variety. Very popular with its clear pink flowers.

L. purple-Flowers of medium size are light purple shading to bluish-pink as they fade.

LANTANA-A very showy, hardy shrub with verbena-like flowers. Especially fine for bedding or baskets. Is almost continuously covered with bloom. $35 \mathrm{c}$ and $50 \mathrm{c}$.

L. alba perfecta-Flowers white with yellow centers.

L. Craig - Flowers orange yellow changing to crimson. Free bloomer.
L. Mer. Jaune-Flowers changing from deep yellow to deep orange.

L. Mrs. McKinley or Weeping Lantana - This variety is especally fine for hanging baskets, window boxes or vases. Flowers of a delicate rosy lilac are borne freely all over the plant from the base of each leaf stalk.

LIGUSTRUM amurense (Amoor River Privet)-A fine hedge plant and may be pruncd to any desired form. A thickly branched variety of rapid growth with small evergreen leaves. Would strongly advise planting during the winter months only. Set in two rows alternating plants 2 feet apart and 12 inches between rows. Fiom open ground $\$ 5.00$ to $\$ 8.00$ per 100 .

MALVAVISCUS arboreus (Japanese Hibiscus) - A very rapid growing shrub of easy culture, resembling the Hibiscus. Bears quantities of beautiful bright red bell-shaped flowers and is almost continuously in bloom. Sometimes called the "Turks Cap." When pruned it makes a very handsome and satisfactory hedge. $25 \mathrm{c}, 35 \mathrm{c}$ and $50 \mathrm{c}$.

MICHELIA fuscata (Banana Shrub)One of the most popular and desirable evergreen shrubs for planting in the middle or lower South. Flowers, which appear during the spring, are yellow with carmine edge and have a banana-like fra- 


\section{SHRUBS AND FLOWERING PLANTS - Continued}

grance. Leaves are broad, dark green and glossy. $\$ 1.00$ and $\$ 2.00$.

NERIUM (Oleander)-One of the most satisfactory, free-blooming evergreen shrubs adapted for Florida planting. Hardy as far north as Central Georgia. It is also valuable as a tub plant for the home in the North. The leaves are long and narrow. The flowers, which are borne in loose clusters, are very showy and produced freely.

N. aurea-Flowers single, cream colored. $35 \mathrm{c}, 50 \mathrm{c}$ to $\$ 1.00$.

N. DeBrun-Double, deep crimson flowers. $50 \mathrm{c}$ to $\$ 1.00$.

N. Madonna grandiflora-Double white flowers of large size. The most popular of the double whites. $50 \mathrm{c}$ and $75 \mathrm{c}$.

N. splendens-One of the most common. It is very pretty with its double pink fragrant flowers. 35c, 50c and $75 \mathrm{c}$.

PLUMBAGO capensis - One of the showiest and most satisfactory shrubs

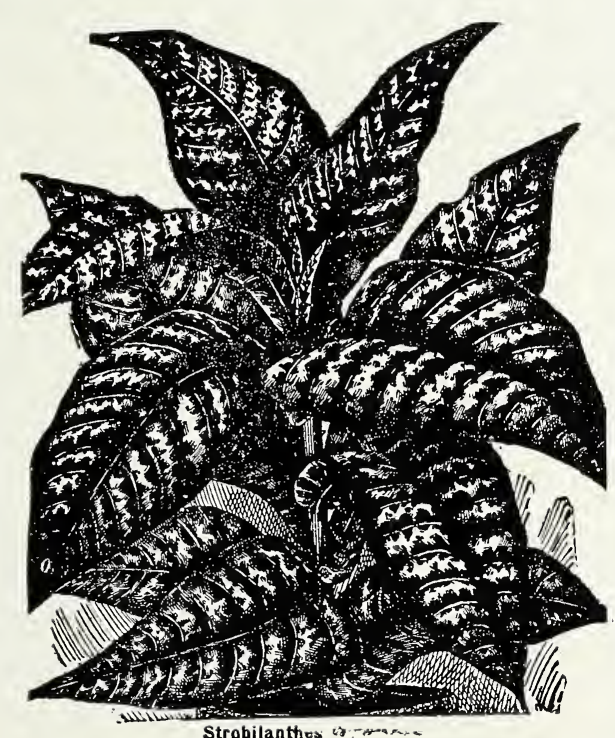

Strobilanthes: is - wasen

\section{Foliage and Decorative Plants}

ACALYPHA - This is a dwarf foliage plant with broad green leaves with cream colored margins and lightly suffused with pink. $35 \mathrm{c}$ to $\$ 1.00$. and $\$ 2.00$. for Southern Florida, constantly bearing quantities of large trusses of light blue flowers. $35 \mathrm{c}$ to $\$ 1.00$.

PITTOSPORUM tobira-A fine shrub with dark, glossy green leaves and fragrant, yellowish white flowers of small size. Suitable for hedges or specimen plants. Especially well adapted for seashore planting as it withstands the strong salt winds exceptionally well. $35 \mathrm{c}$ and $50 \mathrm{c}$; strong plants $\$ 1.00$ to $\$ 2.00$.

P. tobira variegata-Similar to P. tobira, but with leaves beautifully variegated with white and lighter green color. Of dwarf habit. 50c; large plants $\$ 1.50$

STENOLOBIUM (Yellow EIder)-A tall, rapidly growing evergreen shrub producing quantities of fragrant yellow flowers in autumn. $35 \mathrm{c}$ and $50 \mathrm{c}$; strong plants $75 \mathrm{c}$ and $\$ 1.00$.

STROBI-LANTHES anisophyllus - A small plant, with long, narrow, lavender tinted leaves. $35 \mathrm{c}, 50 \mathrm{c}$ and $75 \mathrm{c}$.

S. dyerianus - Very ornamental as a pot plant with its broad purplish leaves, with silvery stripes. Bears sky-blue trumpet-shaped flowers in spring. 35c, $50 \mathrm{c}$ and $75 \mathrm{c}$.

TABERNAEMONTANA coronaria (Crape Jessamine or Rose Bay)-A beautiful shrub with dark, glossy green leaves, and large, pure white double flowers. Blooms at intervals throughout the year. 50c; large plants $75 \mathrm{c}$ to $\$ 1.50$.

THEVETIA nerifolia (Trumpet Flower)-The seeds of this plant are known as "Lucky Seeds," and the fruits as "Tiger Apples." It is an attractive shrub, growing 6 to 10 feet high, with narrow shining leaves and long trumpet-like yellow flowers. $35 \mathrm{c}$ to $\$ 1.50$.

THUNBERGIA erecta - A fine small shrub growing about 4 to 5 feet high with smooth dark-green leaves and bearing gloxinia-like royal purple flowers with yellow centers. Blooms almost continually throughout the year. $35 \mathrm{c}$ and $50 \mathrm{c}$; tub specimens $\$ 1.00$ to $\$ 2.00$.

A. marginata-The largest of all the Acalyphas, growing in open ground up to 8 feet high. Leaves green edged with cream and different tints of pink, ribs and veins also pink. Very rapid grower. 


\section{FOLIAGE AND DECORATIVE PLANTS-Continued}

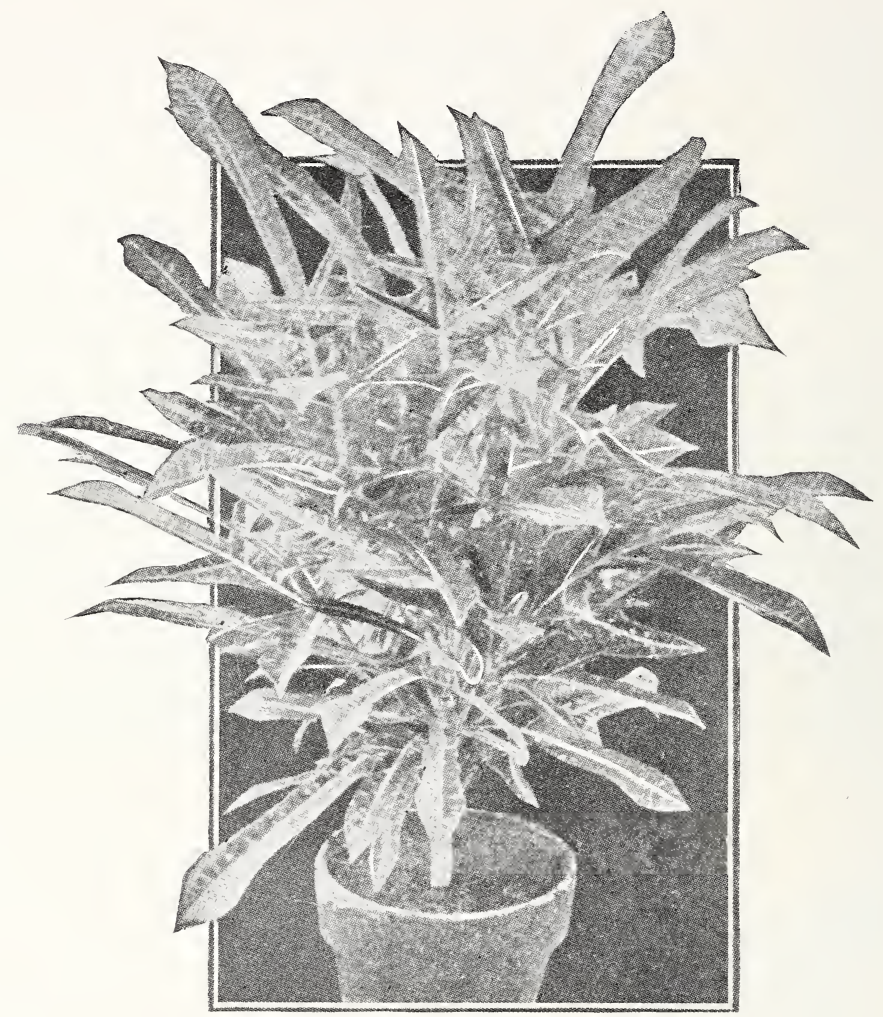

\section{PHYLLAUREA...(Croton)}

A. mosaica-Very showy plant, 4 to 6 feet high, with its mosaic leaves showing all shades of green, yellow and red, with curious markings. A very fine decorative plant for the lawn. Made-up tub specimens $\$ 5.00$.

A. Sanderii (The Chenille or Comet Plant)-It is of strong free growth with large, dark green leaves from the axil of which rope-like spikes from one to two feet long, and nearly one inch thick, are gracefully suspended.

A. tricolor-Resembles the Mosaica, but with regular foliage, mostly red.

ACHYRANTHES-These plants make intensely bright beds and show off splendidly in borders to taller growing plants. Thrive in any soil and are not easily killed by frost. Bedding size 75c per dozen; larger plants $25 \mathrm{c}$ to $50 \mathrm{c}$.

McNally Round-Broad leaf, variegated green and yellow.
ASPIDISTRA veriegata-A very attractive plant with broad green leaves striped with white. Very desirable as a pot plant for the house or porch. $10 \mathrm{c}$ per leaf.

BEGONIAS-There is no more interesting class of plants than this large genus. It embraces hundreds of species, besides thousands of varieties. They are suitable as pot plants for the house or porch. The foliage as well as the flowers are extremely ornamental, some being spotted and veined to give a parti-colored effect that is very striking.

We carry a large assortment of the beautiful flowering varieties; white shades of pink and red. 25c. to $\$ 1.00$.

Begonia Rex-The broad, high colored leaves with exquisite markings make the Rex Begonias invaluable as a decorative plant for the house. They are also excellent for baskets and vases if given plenty of moisture and not exposed to the full rays of the sun. 


\section{FOLIAGE AND DECORATIVE PLANTS-Continued}

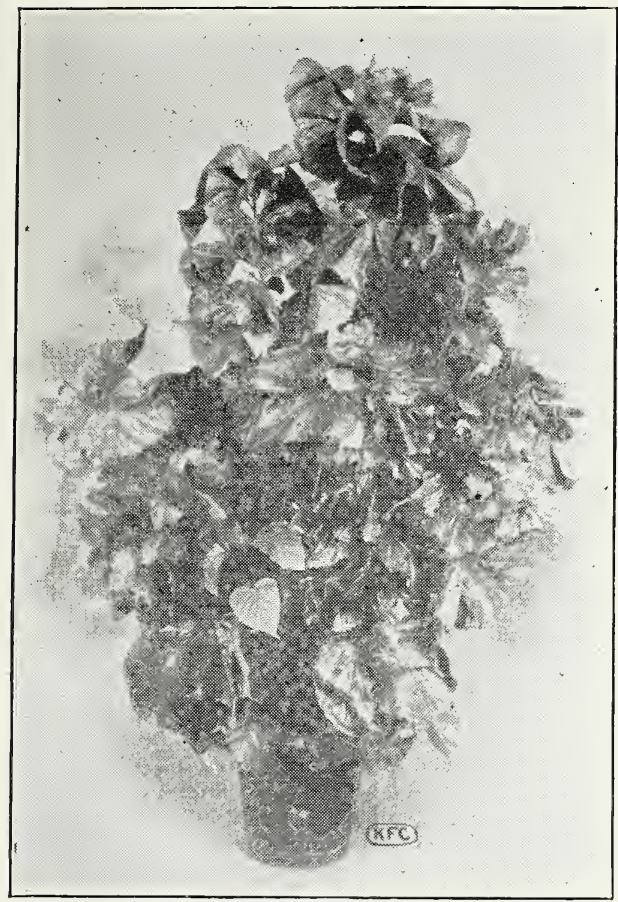

ACALYPHA MOSAICA

Ricinifolia or Star Begonia-A fine tropical looking plant with large ricinus-

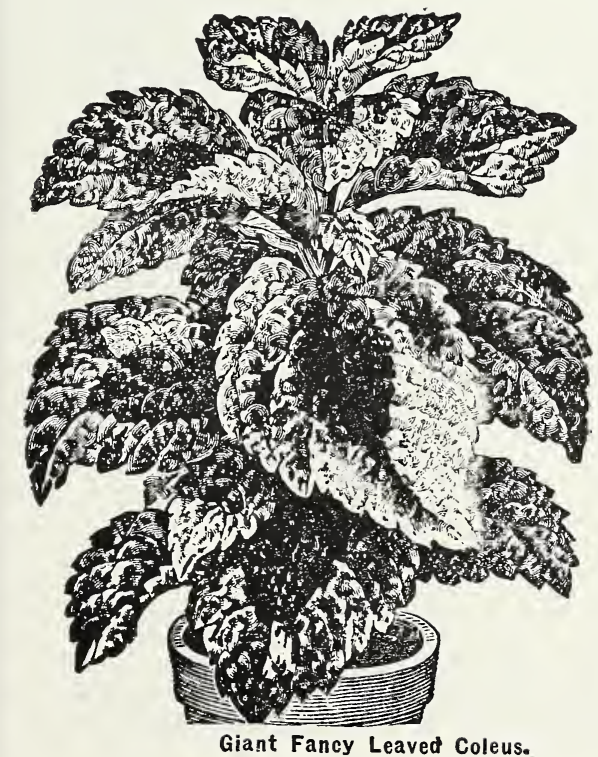

Page Twenty-One like leaves; deep green above and purplish-red underneath. The flower stems rise above the foliage, bearing fine large panicles of beautiful pale pink flowers. Fine pot plant and grows very large when planted outside.

Rubra-Flowers are rich coral-red hanging in large pendant clusters.

COLEUS brilliantine-One of the finest of the Coleus family with its immense leaves showing bright pink, chocolate and purple with scalloped edge of green and yellow. 25c, $35 \mathrm{c}$ and $50 \mathrm{c}$.

Xmas Gem $\longrightarrow$ A very bright variety with smaller leaves than brilliantine, but about the same markings. 25c, 35c and $50 \mathrm{c}$.

We also have a large variety of bedding Coleus. See Bedding Plants.

C UPHEA hyssopifolia (Erica) - A small shrubby plant with very small narlow leaves bearing continually tiny lavender flowers. Very attractive for window boxes and especially fine for borders. When used for borders set 8 inches apart. $10 \mathrm{c}, 15 \mathrm{c}$ and $25 \mathrm{c}$.

DRACAENA - These plants are considered among the best of decorative foliage plants. They should be given a light fibrous soil with good drainage, liberal

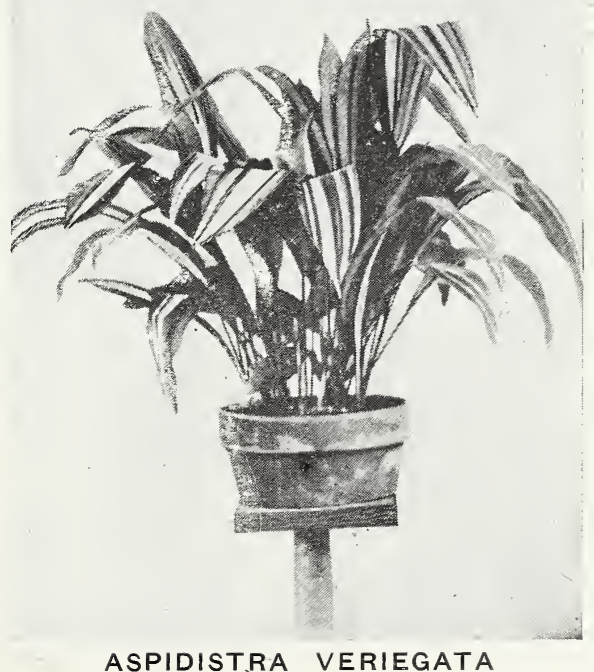




\section{FOLIAGE AND DECORATIVE PLANTS-Continued}

watering with frequent showers. To ensure the greatest development of color let them have all the sunshine available.

Fragrans-A fine decorative plant with broad plain green leaves. $\$ 1.00$ to $\$ 5.00$.

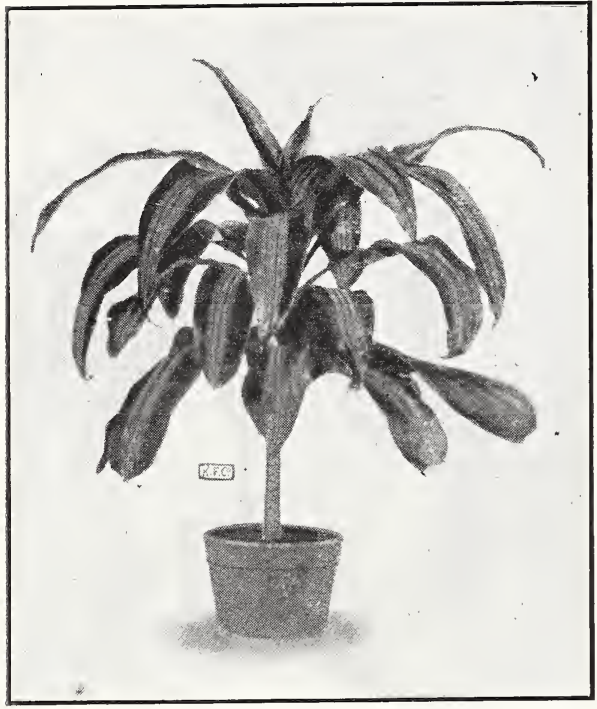

DRACAENA MASSAGEANA

Massangeana-Similar to Fragrans, except leaves have a broad golden yellow stripe through the center. $\$ 2.00$ to $\$ 5.00$.

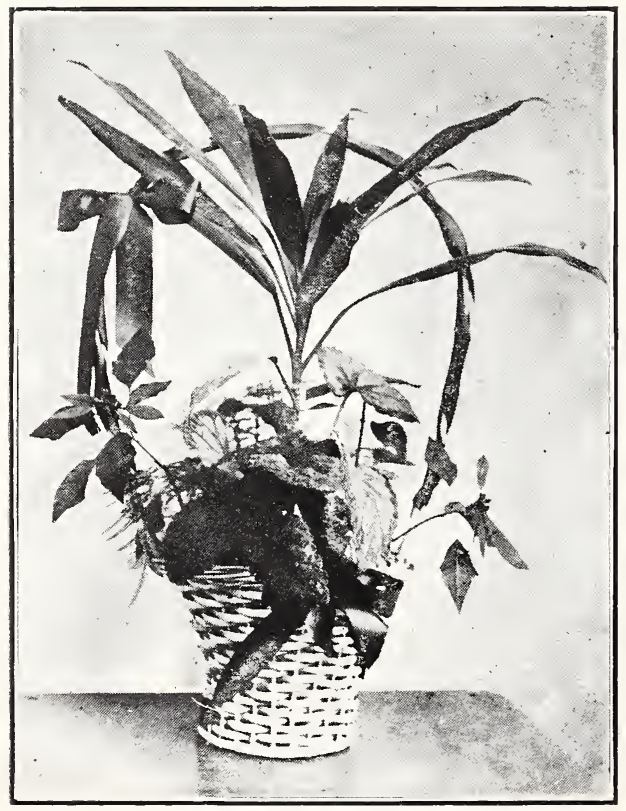

Terminalis-One of the finest for decorative purposes. Leaves are rather long and pointed, of rich crimson color streaked with pink and white. $\$ 3.00$.

PANDANUS utilis (Screw Pine)-Very odd and attractive plant with its spirally arranged leaves which have small red spines along the edge. Somewhat resembles the pineapple plant. A very symmetrical and handsome plant suitable for vases. $\$ 1.50$ and $\$ 2.00$; large specimen plants $\$ 8.00$.

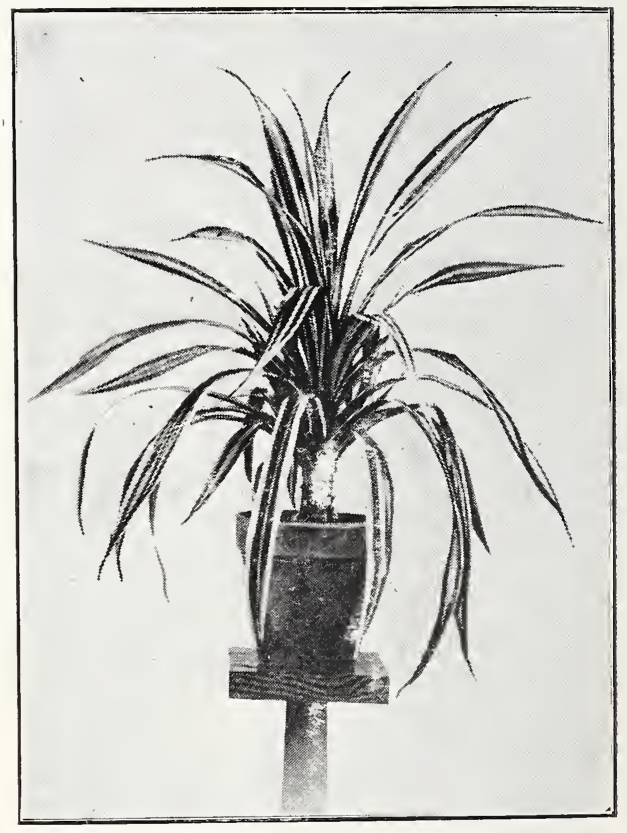

PANDANUS VEITCHII

Veitchii-One of the most attractive decorative plants, especially fine for urns, etc. Leaves are beautifully striped with white. $\$ 1.50$ to $\$ 2.00$; specimens $\$ 8.00$ to $\$ 10.00$.

PHYLLANTHUS nivosus var. roseopictus - Shrub with rather loose wiry branches somewhat zigzag. Leaves beautifully mottled with green, white, pink and red. Fine for low hedges, borders, etc. $35 \mathrm{c}, 50 \mathrm{c}$ and $75 \mathrm{c}$.

\section{PHYLLAUREA (Croton)}

These plants with their gorgeous colorings of red, yellow, green, white and bronze make them one of the most excellent for decorative purposes. They require plenty of heat and moisture. We carry a large assortment of the different varieties. $15 \mathrm{c}$ to $75 \mathrm{c}$; large, strong plants $\$ 1.00$ to $\$ 5.00$. 


\section{FOLIAGE AND DECORATIVE PLANTS-Continued}

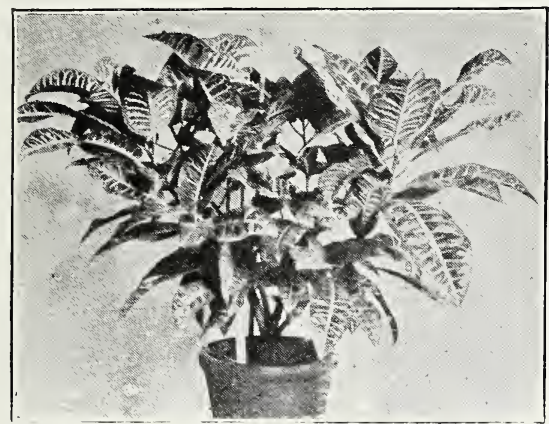

PHYLLAUREA veriegata (Crotons)Tuberous, Bulbous, and Herbaceous Plants

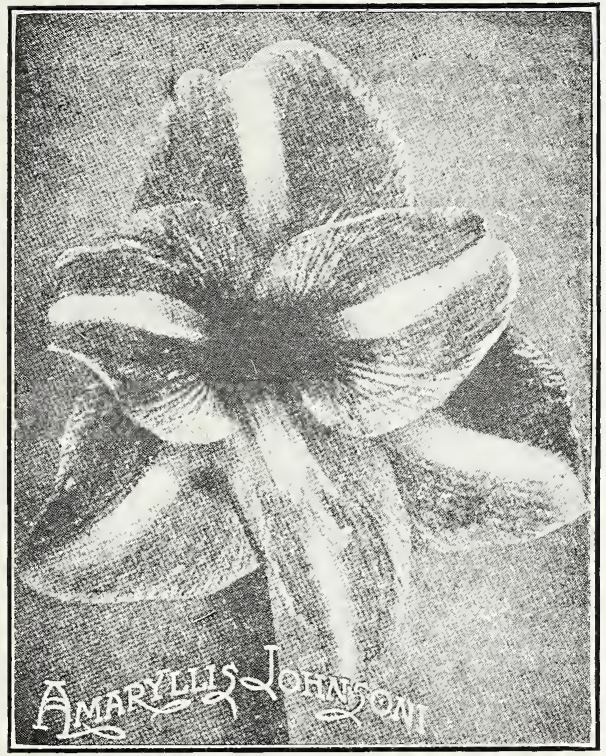

AMARYLLIS (Johnsoni) - Fine for bedding and window boxes, producing under the simplest conditions one, two or even three spikes, three feet or more high, which are crowned with from three to six large and gorgeous trumpet-shaped flowers of crimson-scarlet color striped with whie. Prices on application.

BEGONIAS tuberous rooted-We carry a fine line of assorted colors when in season. Write for prices.

CALADIUMS fancy assorted-Leaves beautifully marked with bright colors. $35 \mathrm{c}, 50 \mathrm{c}$ and $75 \mathrm{c}$.
TRADESCANTIA (Wandering Jew) This is a beautiful trailing vine with thick, waxy foliage; very useful in baskets and window boxes. 10c each; $\$ 1.00$ per dozen.

Striata - Bright green leaves striped with creamy white.

Tricolor-Leaves are green, purple and creamy white. 10c each;

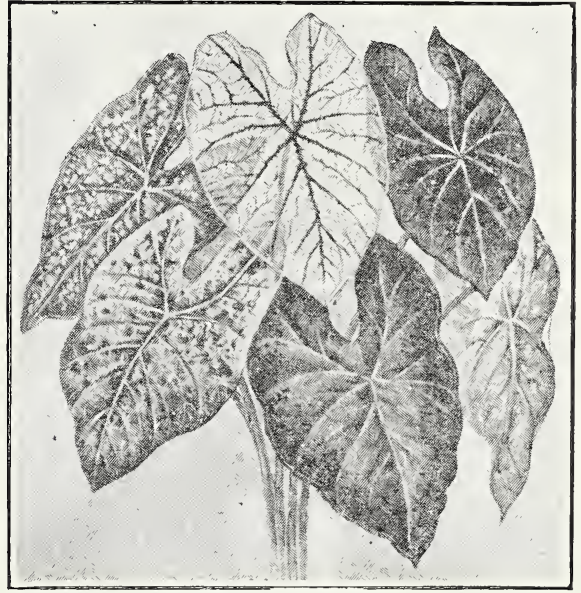

CALADIUMS

CALLA LILY (Godfrey Ever-blooming) Very popular variety for either pot plant or outdoor planting. Flowers are pure white. 50c; strong blooming plants $\$ 1.00$ to $\$ 3.00$. Bulbs should be planted in October or November. Prices on application.

CANNAS - This is one of the finest plants for general planting. Will thrive in any kind of soil and most any location, but to obtain best results they should be given an open, sunny location, rich soil and plenty of water. Our collection contains the best varieties, both green and bronze foliage and are orchid flowering. 15c each; $\$ 1.50$ per dozen.

Allemania-Dark salmon with golden markings. 
KNULL FLORAL COMPANY, TAMPA, FLORIDA

TUBEROUS, BULBOUS AND HERBACEOUS PLANTS-Cont.

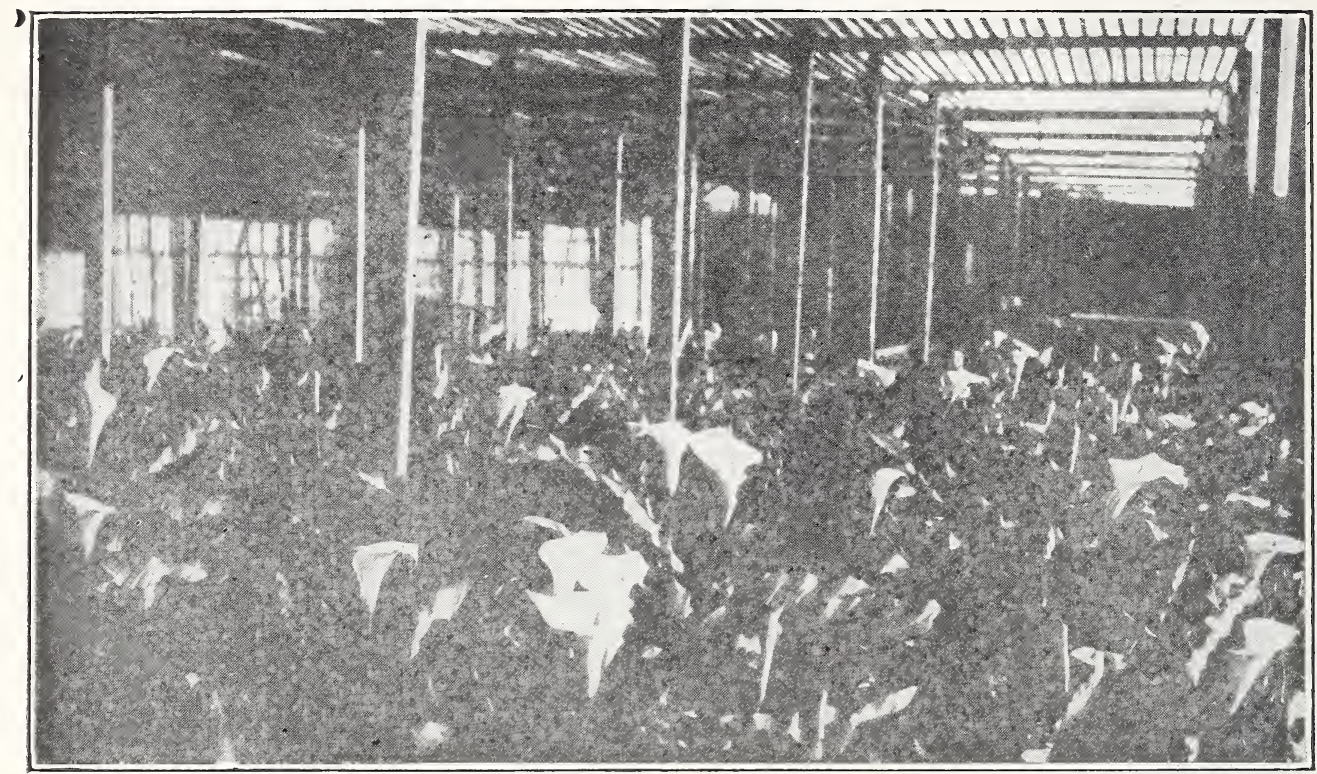

CALLA LILIES IN SLAT HOUSE

Austria-Pure canary yellow with crimson dots in throat.

Coronet-Canary Yellow.

Edulis-A foliage variety grown as a food.

Indiana-Golden orange finely striped with red. Single bloom often measures seven inches across.

King Humbert - The grandest of all

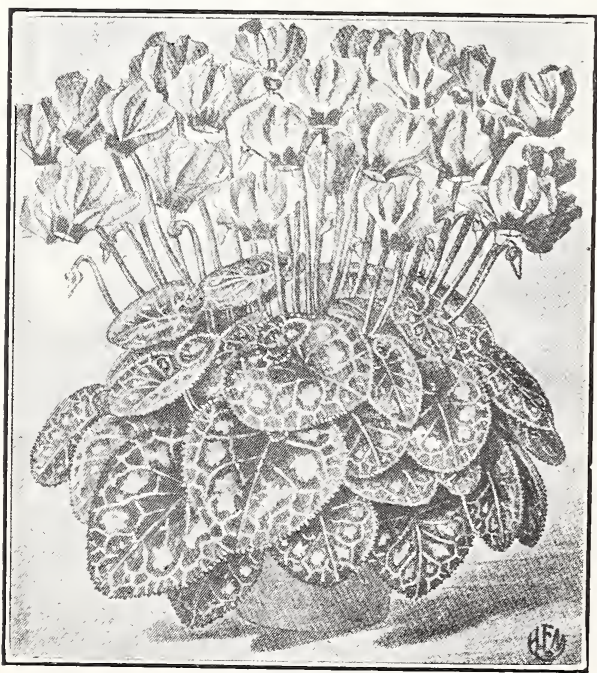

CYCLAMEN cannas with its bronze foliage and immense trusses of large sized flowers, which are orange scarlet with bright red markings. 25c each; $\$ 3.00$ per dozen.

Louisiana-Large flowers of vivid scarlet. $25 \mathrm{c}$.

Pennsylvania - Large flower's of a vermillion scarlet often seven inches across. $25 \mathrm{c}$.

Wintzer's Colossal - Without a doubt 1bus is the largest flowered canna. Tne vivid scarlet flower often measures over eight inches across.

Yellow King Humbert-Similar to King Humbert, only foliage is rich green instead of bronze and has brilliant yellow flowers of immense size instead of red.

CYCLAMEN - These ar'e fine house plants with foliage beautifully variegated with silver and rose and inverted waxy flowers of various colors, pink, purple, red and white; produced in profusion for several months. Quite fragrant. Plants in bud and bloom $\$ 2.00$ to $\$ 7.00$.

E A S T E R LILIES - Few flowering plants can be of more interest in the garden than the well-known Easter Lily. It is of easy culture and no flower is more beautiful than this fragrant pure white lily. Plant during October and November. Frice on application. 


\section{TUBEROUS, BULBOUS AND HERBACEOUS PLANTS.---Cont.}

\section{EUCHARIS Amazonica (Amazon Lily)}

A fine pot plant producing fragrant, pure waxy white star-shaped flowers often about four inches long. Small plants $35 \mathrm{c}$; larger 50c; specimen plants $\$ 1.00$ to $\$ 2.50$.

FREESIAS - These graceful fragrant flowers are of the easiest culture. Can be grown as a pot plant or in the open ground. They require a good loam with some well rotted manure or leaf mold and should not suffer for water. Plant in October and November. Write for prices.
GLADIOLUS-This is one of the most popular of the flowering bulbs. In South Florida can be planted from October to January. We only carry a few of the best varieties. Bulbs $75 \mathrm{c}$ per dozen.

America-This is one of the finest for cut-flowers or for bedding out. Produces long spikes with exceptionally large orchid-like flowers of a very beautiful delicate pink.

Brenchleyensis - Flowers are vermillion scarlet.

Mrs. Francis King - A very striking shade of light scarlet.

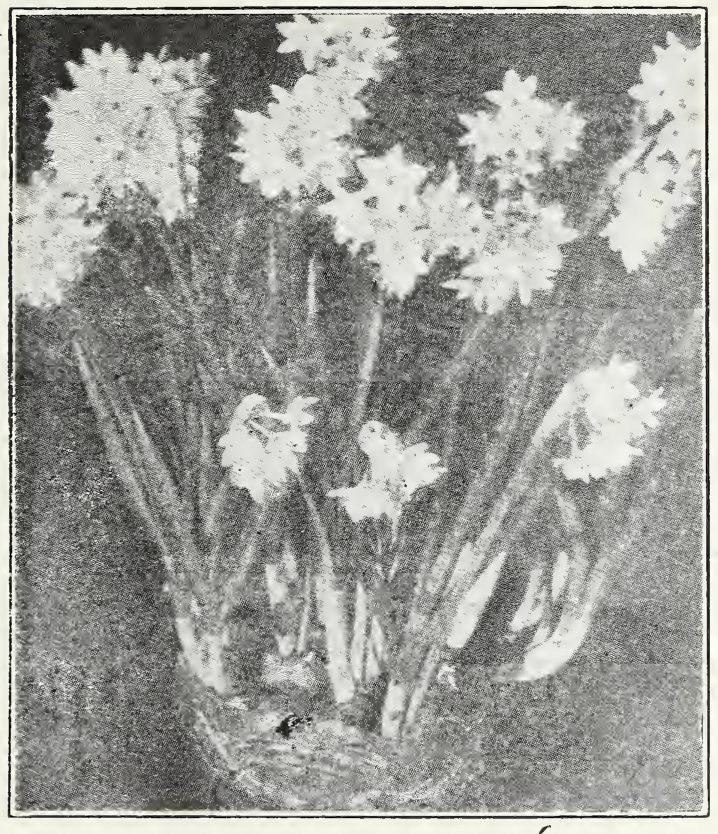

NARCISSUS, PAPER WHITE

NARCISSUS grandiflora (Paper White)-May be planted from October to February in open beds, pots and window boxes; also can be grown in glass bowls of water same as the Chinese Sacred Lily. Bears long stemmed clusters of pure white star-shaped flowers. $50 \mathrm{c}$ per dozen.

\section{Roses}

Roses are one of the most important flowering shrubs of the South, and, if properly cared for, will produce an abundance of bloom nearly the entire year. They require very rich, well-drained soil, and should be fertilized several times a year, also see that they never want for moisture at the roots. Keep the soil moist to a depth of 2 feet at all times, if possible. Enough pruning should be done to keep them free from old wood, but if more is necessary, it should be done about October in order to encourage long flowcring shoots. Transplant roses in November, Decemser or January.

Appreviations used: (H. P.) Hybrid Perpetual; (H. T.) Hybrid Tea; (Beng.) 


\section{ROSES-Continued.}

Bengal; (N) Noisette; (H. N.) Hybrid Noisette; (T.) Tea; (Cl.) Climber.

Price: Our roses are 2-year grafted stock and 75 cents each, except where otherwise stated.

Black Prince. (H .P.)-Upright, strong grower, bearing flowers of a velvety crimson with shadings of purplish black.

Chromatella. N. Cl. Sometimes called "Cloth of Gold." One of the best yellow climbers. Lemon-yellow color with long, pointed buds. Vigorous climber and a good bloomer. Fragrant.

Devoniensis. T. Cl. Sometimes called the "Magnolia Rose" on account of the large blooms and thick waxy petals. Flowers are white tinged with delicate pink. Strong climber.

Duchess de Brabant. (T.) One of the best all-round roses ever introduced. A good grower, constantly in bloom. Flowers light rose shading to salmon.

Etoile de Lyon. (T.) Bright sulphuryellow; fine form; large size; a fine yellow rose.

General Jacqueminot. (H. P. Bush.)Large, brilliant red, fragrant flowers with long stems. This is an old variety, but always popular.

Helen Gould. (H. T.)-Beautiful rosy crimson blooms of splendid form and tex. ture. Long pointed buds, lasting well when cut. Vigorous, spreading grower.

J. B. Clark. (H. P.)-Strong growing variety, with flaming scarlet flowers, borne on upright, stiff stems .

Kaiserin Auguste Victoria. (T. Bush.) A free bloomer from early spring to late fall. Flowers are pure white, with shadings of primrose yellow.

Kaiserin Auguste Victoria. (CI.)-A strong climbing form of the other variety of the same name. Pure white flowers.

Louis Phillippe. (Beng. Bush.)-This is an old favorite. Strong, healthy grower and produces an abundance of dark red flowers.

Maman Cochet. (T. Bush.)-A strong, vigorous grower and profuse bloomer. Flowers are pure white, or white with a very slight, delicate pink tint on the outer petals.
Maman Cochet. (T. Cl.) - This is a climbing form of the rose of the same name. Grand, huge white flowers tinged pink. On own root. $\$ 1.00$ each.

Maman Cochet Pink (T.)-Beautiful light pink shaded with salmon yellow; outer petals splashed with bright rose; extremely large and full.

Marechal Niel (Cl. N.)-This is the old standby of the South, where it is hardy. Immense deep golden-yellow flowers, very fragrant. On own root, $75 \mathrm{c}$ and $\$ 1.00$.

Mrs. Dudley Cross. (H. T.)-Beautiful creamy-white with edge of petals carmine and rosy yellow at base. Fine formed buds opening into full double blooms. Strong, vigorous grower of spreading habit.

Ophelia. (H. T.)-Large, perfect shaped flowers of a brilliant salmon-flesh shaded with rose on outer edges of petals, with a heart of glowing peach-pink and orangeyellow blendings. Erect habit, stiff long stems, free and continuous in growth and bloom.

Papa Gontier. (T.) - Long, brilliant cherry-red buds, semi-double. An abundance of bloom is produced at all seasons. Medium, upright growth.

Paul Neyron. (H. P.)-The largest flowered rose grown, often measuring five inches in diameter. Color is a deep shining pink. Strong and vigorous. A very desirable variety.

Pierre Guillot. (H. T.)-Large, handsome buds opening to flowers of the deepest, richest red. Medium upright habit.

Radiance red. (T. Bush.)-One of the finest red roses. Flowers of exquisite form, are deep, rich red, which does not readily fade. The stems are long, which makes it very valuable for cut-flowers. Two-year grafted, $\$ 1.00$ each.

Radiance pink. (T. Bush.)-A fine pink rose. The cup-shaped flowers are a beautiful shade of soft carmine-pink, deeper on the outside than on the inside of the petals. Flowers very large on long stems. Strong growing variety. Two-year grafted, $\$ 1.00$ each. 


\section{ROSES-Continued.}

Reine Marie Henriette. (CI. T.)-Deep cherry red. Fine buds opening into large delicately scented blooms. Vigorous climber and good bloomer. Own root, 75c. Two-year grafted, $\$ 1.00$ each.

Reve d'Or. (T. CI.)-Deep coppery-yellow, fragrant blooms. One of the best yellow climbers.
Safrano. (T. Bush.) - Strong growing rose, producing salmon-colored buds of exquisite shape and semi-double flowers. Profuse bloomer. A very old rose, but always a favorite.

Solfatare. (T. Cl.)-Flowers are a clear sulphur-yellow, large, double and wellformed. Free bloomer and may be pruned to bush form.

\section{Vines and Creepers}

A screen of vines on the porch adds not only comfort to the home, but beauty as well. They can also be trained on trellises, pergolas, arbors, etc., where they are naturally invaluable. If unsightly fences, which are usually necessary, were covered by them they would soon be things of beauty, as vines not only soften the lines, but cover up many imperfections. In planting the ground should be prepared and fertilized the same as for any shrub.

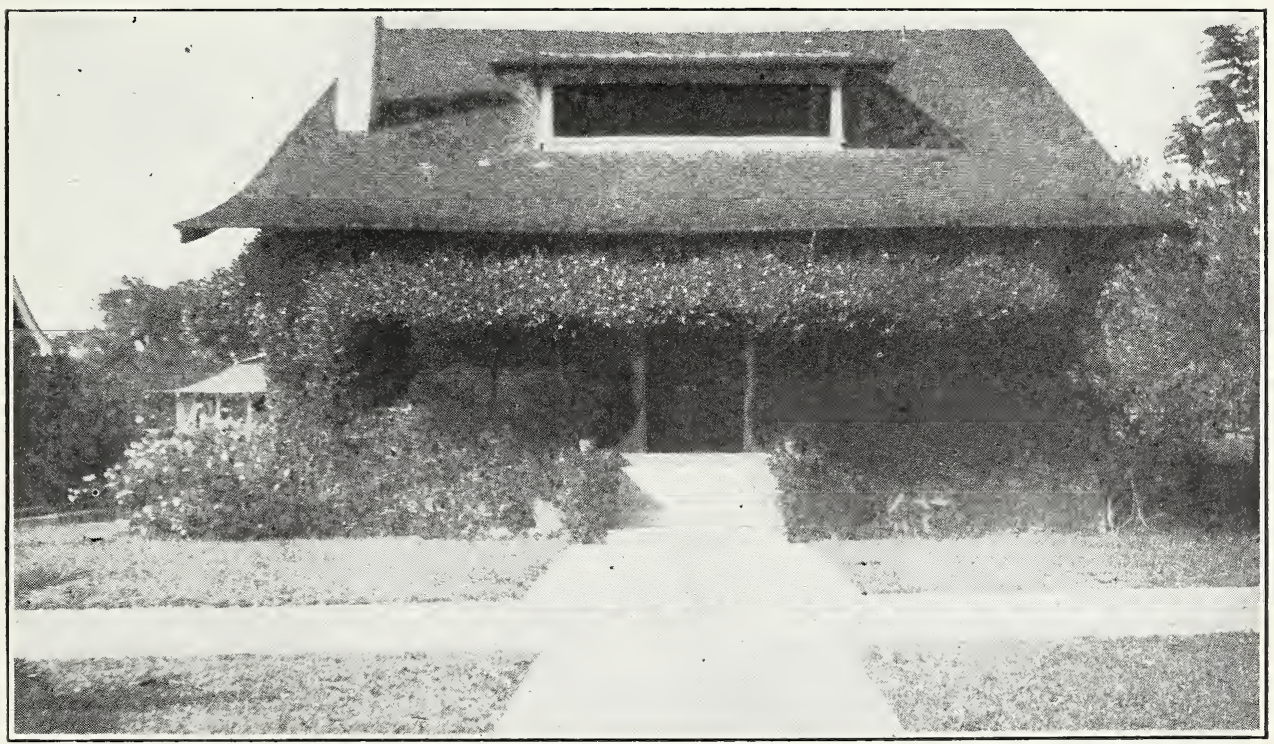

FICUS REPENS (Climbing Fig)

The photograph above gives a very good illustration of the wonderfully beautiful covering that this vine makes. This one was planted by us only about six years ago. The leaves are round, small and evergreen. The possibilities of this, the most satisfactory creeper, are almost unlimited. It will cling equally well to a smooth brick wall as to wood. If you have about your home an unsightly wall or old chimney, you should by all means plant one of these pretty evergreen vines to make it an attraction to your home instead of an unsightly object.

ALLAMANDA carthartica hendersonii. A beautiful tropical plant grown in Florida which may be trained to be either a shrub or vine, Glossy green broad leaves; flowers, which are constantly produced, are pure golden yellow and of large size. Strong plants $35 \mathrm{c}$ and $50 \mathrm{c}$.

Page Twenty Seven
ANTIGONON leptopus (Rosa de Montana)-A beautiful vine bearing great racemes of rose-pink flowers for most of the year in Florida, good for sunny locations. $25 \mathrm{c}$ and $35 \mathrm{c}$. 


\section{VINES AND CREEPERS - Continued}

AMPELOPSIS veitchii (Boston Ivy) A well-known rapid climber with dark green foliage assuming brilliant shades in fall. Three years old $75 \mathrm{c}$.

BEAUMONTIA grandiflora-A strong growing, woody vine with large dark green foliage and clusters of immense trumpet-shaped white flowers resembling the Easter Lily, only larger. Strong layer plants $\$ 1.00$ to $\$ 2.00$.

BIGNONIA Unquis-Cati (Cat's Claw Vine.)-A hardy evergreen vine, producing an abundance of bright yellow flowers in early spring. Very rapid growing.

BIGNONIA venusta (Pyrostegia)-One of the strongest growing vines climbing to a great height. Evergreen, with bright, glossy green foliage. Tubular flowers of a bright orange-red color are borne in great profusion during the winter and spring, making it one of the most striking and beautiful of all vines. $35 \mathrm{c}, 50 \mathrm{c}$ and $75 \mathrm{c}$.

BOUGAINVILLEA braziliensis - The Bougainvillea is very popular and one of our finest plants; may be trained to be either shrub or vine. This species has flower's of a rich purple. $50 \mathrm{c}$ to $\$ 2.00$.

Crimson Lake-Very beautiful. Flowers, rich crimson, later overcast with purple shades. Strong plants $\$ 2.00$ to $\$ 4.00$; specimen plants $\$ 5.00$ to $\$ 10.00$.

Glabra Sanderiana (Japanese Paper Flower) - The best known variety. A strong grower. A very showy plant bearing masses of purple flowers during winter and spring but showing some bloom most of the year. 35c. to $\$ 2.00$.

CLERODENDRON Thomasae (Bleeding Heart)-A beautiful climbing plant of very rapid growth. Flowers of a bright scarlet, enclosed partly in a pure white calyx, are borne in great profusion. Young plants a foot high often bearing several clusters. $35 \mathrm{c}$ and $50 \mathrm{c}$.

FICUS repens (Climbing Fig) - An evergreen climber with small green leaves. Makes a very dense, dark green covering; excellent for walls, rock or rustic work, as it attaches itself to any solid object. $35 \mathrm{c}$ and $50 \mathrm{c}$.

GELSEMIUM sempervirens (Yellow Jasmine)-Well known woody vine bearing glossy evergreen foliage and a profusion of fragrant, bell-shaped, bright yellow flowers in winter. $35 \mathrm{c}$ and $50 \mathrm{c}$.
HEDERA helix (English Ivy) - The well-known ivy used for covering walls, etc. Foliage is very rich, waxy green, with prominent veins. $35 \mathrm{c}$ and $50 \mathrm{c}$.

IPOMEA bona-nox (Moonvine) - A very quick-growing vine, bearing large white flower's with a five-pointed star in center. Flowers open only at night. $35 \mathrm{c}$.

IPOMEA horsfalliae-This is a lovely viine with waxy, dark-green leaves, bearing showy carmine colored flowers in December, also blooms lightly in June. $\$ 1.00$.

IVY (Parlor Ivy) - This ivy is fine for window boxes and hanging baskets, or training in the parlor. Leaves are glossy green. $15 \mathrm{c}$ each; $\$ 1.50$ per dozen.

JASMINE gracillimum (Star Jasmine) An evergreen climbing shrub with beautiful showy white star-shaped flowers, which are very fragrant. Bright green pinnate foliage. $35 \mathrm{c}$ and $50 \mathrm{c}$.

LONICERA Hall's Japan (Honeysuckle)-Hardy, very vigorous climber. White flowers, changing to yellow, are borne almost constantly. $35 \mathrm{c}$ and $50 \mathrm{c}$.

PYROSTEGIA venusta-See Bignonia.

SOLANUM seaforthianum-A mediumsized delicate vine with compound leaves and bunches of pale lavender-blue flowers, which are followed by scarlet berries. Especially attractive when grown in gar$\mathrm{d} \sim \mathrm{n}$ or on lattice work. $35 \mathrm{c}$ to $75 \mathrm{c}$.

S. Wendlandii-A very large vine with coarse pinnate leaves; beautiful lilacblue flowers are borne in great clusters often 10 to 15 inches across. This is one of the quickest growing vines and thrives in most any kind of soil. $35 \mathrm{c}$ to $75 \mathrm{c}$.

THUNBERGIA grandiflora - A very rapid growing vine with large pointed leaves and a succession of beautiful lavender-blue flowers throughout the year. This vine has become a great favorite. If frozen down it comes right up and is soon blooming freely again. The individual blooms are large and often hang pendant in clusters of several each. $35 \mathrm{c}$ to $\$ 1.00$.

TR A C H E LOSPERMUM jasminoides (Malay or Star Jasmine)-Hardy evergreen vine of rapid growth with small shiny leaves and fragrant pure white star-shaped flowers which are borne in great abundance only in spring. $50 \mathrm{c}, 75 \mathrm{c}$ and $\$ 1.00$. 


\section{Ferns}

There are none of the foliage plants that are more practical for all general house, table or window decoration than the fern. They are easily grown and thrive well in an ordinary living room. They should have plenty of drainage and be kept well watered; never let them dry out for any length of time.

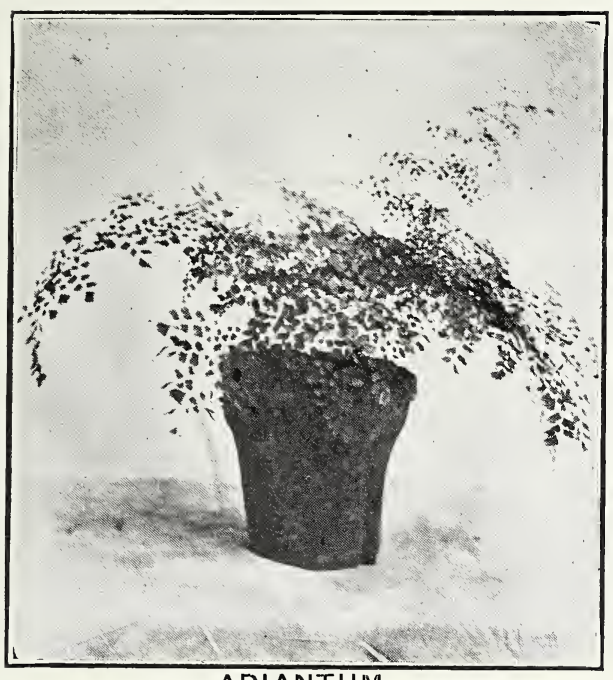

ADIANTUIM

ADIANTUM (Maiden-hair Fern) - We carry a large assortment of the various maiden-hair ferns, listing only a few choice ones. $15 \mathrm{c}$ to $\$ 1.00$.

Croweanum-One of the most beautiful and especially fine for floral arrangements.

Cuneatum-Another very graceful variety with delicate fronds well adapted to cut-flower work.

Farleyense gloriosum (Glory Fern)-A fine specimen of the broad leaf maidenhair.

Mundulum - A dwarf compact plant. Fronds not often more than 9 or 10 inches long, very dark green with wedge shaped pinnae.

Wiegandii-Large plant, compact in habit, reaching a height of 10 to 15 inches.

ASPARAGUS plumosus nanus (Lace Fern)-One of the handsomest and most useful of all ferns. The leaves, very lace like in texture, are bright green. It is especially adapted for bouquets and all cut-flower work. Very easy of culture, thriving best in full light, but not direct sun. $15 \mathrm{c}$ to $75 \mathrm{c}$.

Sprengeri-Strong growing fern forming a large clump of roots and crowns, from which it sends out long shoots covered on all sides with fine branches. Its long pendant-like growth makes it especially desirable for hanging baskets, porch boxes, etc., where it makes a graceful trailing plant with branches or fronds, 4 to 5 feet in length, of a rich shade of green. $15 \mathrm{c}$ to $50 \mathrm{c}$.

NEPHROLEPSIS exaltata Bostoniensis (Boston Fern) - One of the best known of all ferns. Its long, graceful, drooping fronds make it excellent for pedestals. Fully matured fronds attain a length of 4 to 5 feet. $25 \mathrm{c}$ to $\$ 1.00$; specimen plants in tubs, $\$ 2.00$ to $\$ 5.00$.

Davallioides furcans (The Stag-horn)A, fine decorative plant with ends of fronds peculiarly divided. Another common name is "Fish Tail," because ends of fronds somewhat resemble a fish's tail in shape. $35 \mathrm{c}$ to $\$ 1.00$; specimen plants in tubs $\$ 3.50$ and $\$ 5.00$.

TABLE FERNS - These dainty little decorative plants, with their different shades of green and silver, beautifully striped and variegated, are especially adapted for use in jardinieres and are indispensable where inside fern effects are desired. We carry a fine assortment at $15 \mathrm{c}$ to $50 \mathrm{c}$.

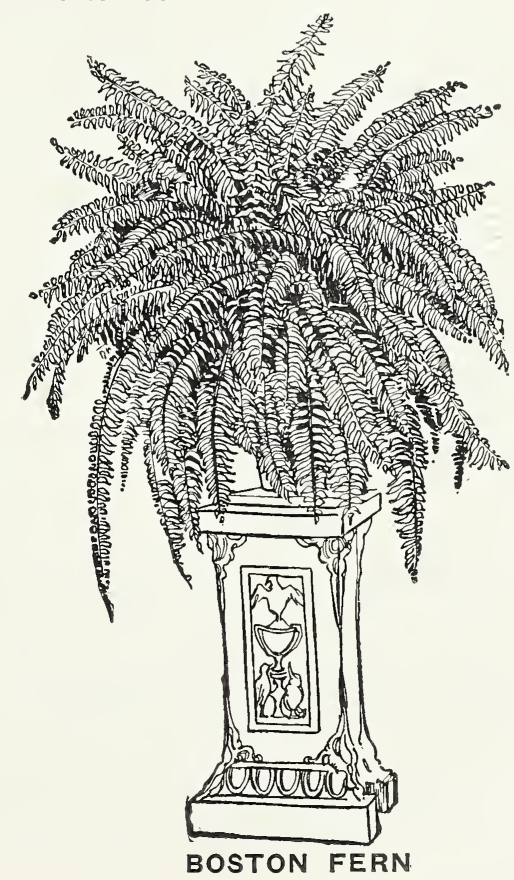


KNULL FIORAL COMPANY, TAMPA, FLORIDA

\section{Bedding Plants}

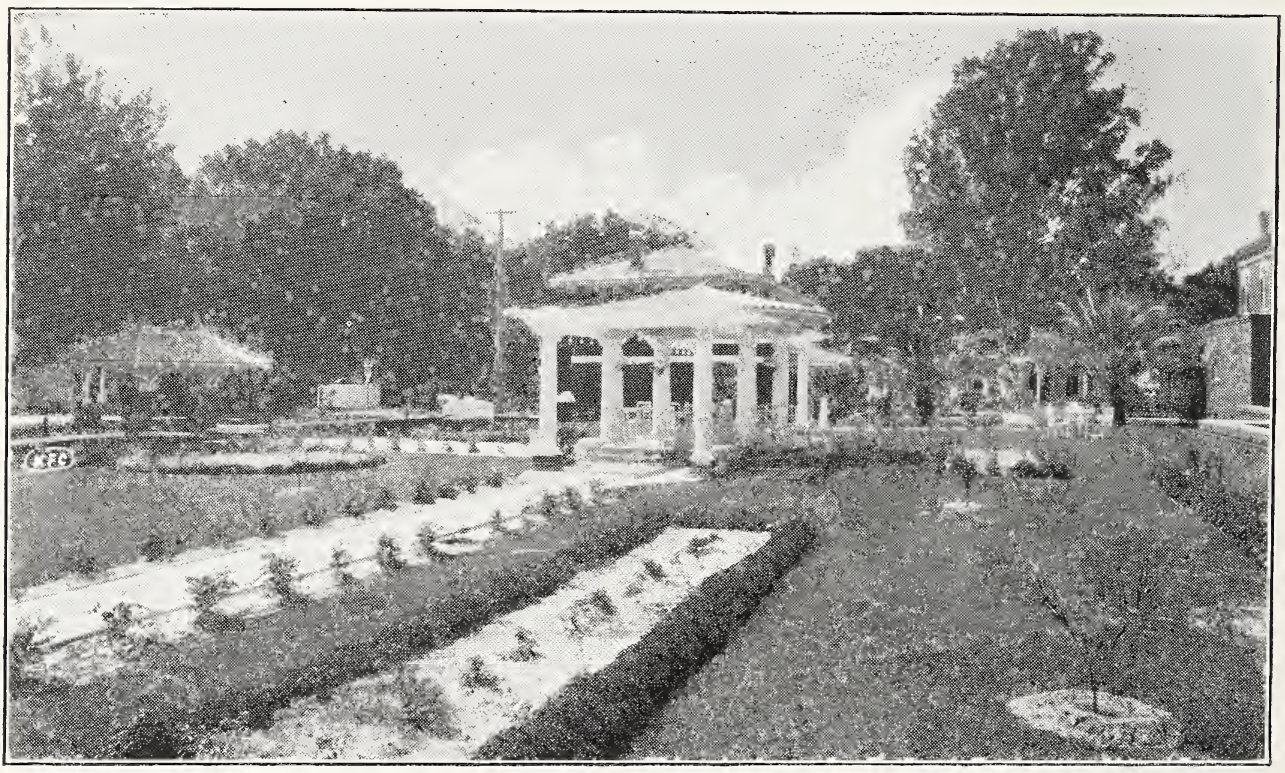

All Bedding Plants are $75 \mathrm{c}$ per dozen or $\$ 5.50$ per hundred and should be set 15 inches apart unless otherwise specified.

AGERATUM inimitable - One of the best of bedders. Nearly always full of immense heads of bright lavender-blue flowers. They are also useful for baskets and vases.

AGERATUM white - Similar to the blue ageratum, only flowers are white. Dwarf.

ALTERNANTHERA-These are dainty little foliage plants of compact habit, growing about six inches high. Very attractive and ornamental for borders. Should be set 4 inches apart.

Aúrea Nana - Fine leaves of bright golden yellow.

\section{Brilliantissima-Bright red foliage.}

ALYSSUM little gem (Sweet Alyssum or Carpet of Snow)-These little plants, 3 to 4 inches high, are fine for borders, setting them 6 inches apart; also are desirable for hanging baskets, trailing over the sides. Produces a profusion of fragrant white flowers.

ANTIRRHINUM (Snap-dragon)-Very popular as a bedder and a cut-flower. Colors are pink, white and yellow.

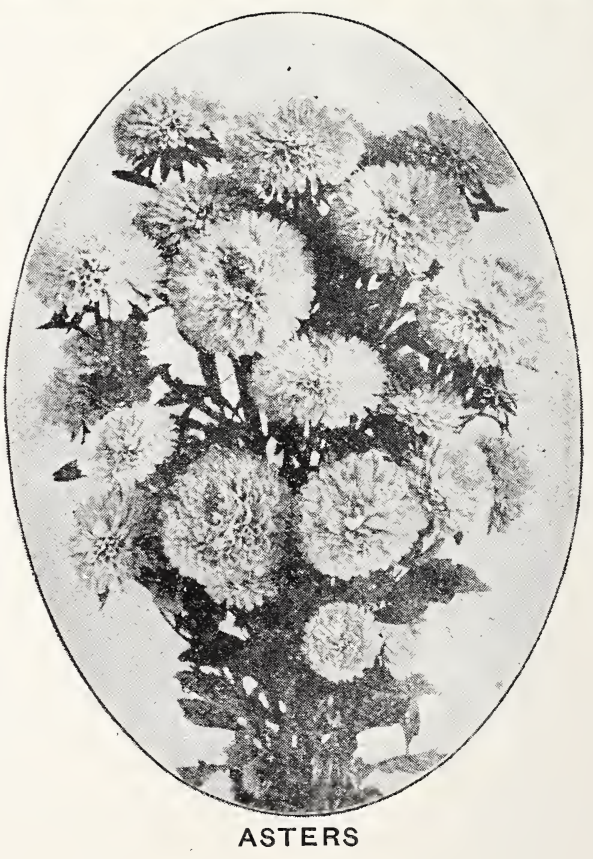

ASTERS-One of the finest of bedders bearing large chrysanthemum-like flowers from March until July. Colors white, pink and purple. 


\section{BEDDING PLANTS - Continued}

BELLIS DAISY-The well known English Daisy. 'They are very attractive little plants growing to about six inches high, which makes them fine for borders or small beds; should be set 6 inches apart. Small double flowers in white and pink.

CALENDULA, Orange King - Hardy annuals about one foot high, that produces a profusion of very showy large double flowers, ranging in color from ivory to deep orange. Makes very attractive beds.

CANDYTUFT - Well known annuals, useful for bedding, set 6 inches apart. White flowers are produced on long spikes.

CARNATION-The carnation is a general favorite, not only for their charming fragrance, but for the richness of color. The most popular carnation for southern planting is the Marguerite. Large double highly-scented flowers are produced on long stems.

CHRYSANTHEMUMS - We carry a fine line of these beautiful plants in both the large flowering and the Pom Pons. Colors are white, pink and yellow in the large flowering, white and yellow in Pom Pons. Plant in April, May or June. $\$ 1.00$ and $\$ 1.50$ per dozen.

COLEUS-We carry a large variety of this well known bedding plant, listing only a few of the best.

Beckwith's Gem-Large, finely scalloped leaves of a dark velvety maroon bordered with red.

Cecil Brown (Trailing Queen)-Small scalloped leaves of dark green centered with magenta and cream. An excellent variety for hanging baskets or vases on account of its trailing habit.

Golden Bedder-Clear yellow when well developed; edge somewhat crinkled; center rib of lighter yellow.

Her Majesty - Rich reddish brown edged with gold.

Leopard-Greenish yellow thickly dotted with maroon.

Silver Queen-Similar to Cecil Brown, except foliage is creamy yellow with narrow bright green border.
DAHLIA-A delightful plant for the garden. They should be set 2 feet apart, given plenty of sunshine and water, and cultivated well until they begin to bloom, after that stir only the surface soil, just enough to prevent a crust from forming. The Cactus Dahlias have large, looselyformed flowers like the Chrysanthemum, while the decorative and show Dahlias produce large ball-shaped blooms, full to the center; the petals are somewhat irregularly situated, long, broad, flat and nearly straight. Dahlias are particularly adapted for seashore use, and not only do well, but thrive, because of the moisture, especially the heavy dews which collect during the night. The Dahlia is one of the easiest plants to grow and will produce more flowers than any other plant in the garden, if properly cared for. For growing in the South plant in the spring. There are many different varieties of this charming plant, of which we carry a few of the best. $\$ 1.00$ and $\$ 1.50$ per dozen.

DAISY Shasta-Very free blooming plant with large pure white flowers with golden centers. $\$ 1.00$ per dozen.

DIANTHUS or Pinks-This is a popular plant for bedding. Flowers in a great variety of colors make them very attractive.

FEVERFEW-A bushy plant bearing a profusion of small, double, white daisylike flowers.

GERANIUMS-There is a large family of the Geranium, of which we have a good collection. $20 \mathrm{c}$ and $25 \mathrm{c}$ each.

Alphonse Ricard - Large trusses of double bright orange-red flowers.

Beaute Poitevine - Semi-double. Free bloomer, bearing large bright salmonpink flowers.

La Favorite-Double. One of the finest, with large trusses of pure white flowers.

Marquis de Castelaine-One of the largest geraniums. Deep rosy scarlet color shading to pure scarlet at edge of upper petals.

S. A. Nutt-Double. Its dark crimson flowers make it the darkest and richest geranium grown. 


\section{BEDDING PLANTS - Continued}

LARKSPUR-This is a quick growing, free blooming annual, producing stiffly erect spik's of beautiful flowers in great profusion. Colors: white, flesh-pink and sky-blue.

P A N S I E S - Pansies produce larger flowers and are at their best during the cool weather. We have a fine collection of rich, velvety shades, many light colors, in great variety and huge in size, with long stems. Should be set 8 inches apart.

PETUNIAS - These brilliant flowers are easily grown and make one of the most desirable annuals. Flowers are large size and colors are indescribably rich and varied.

SALVIA splendens (Scarlet Sage)This is a very popular plant. Its spikes of brilliant scarlet flowers towering above the dark green foliage make of it a very attractive plant.

S. alba - Same as splendens except flowers are creamy white.

STOCKS-Stocks are well adapted for use as bedding plants, pot culture or for cut-flowers. The rosette-like flowers are

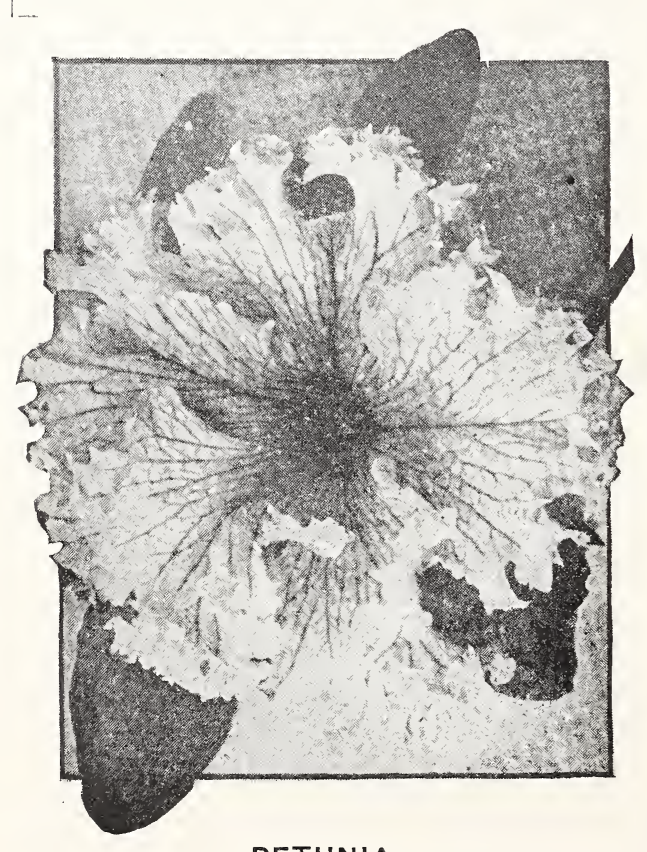

PETUNIA

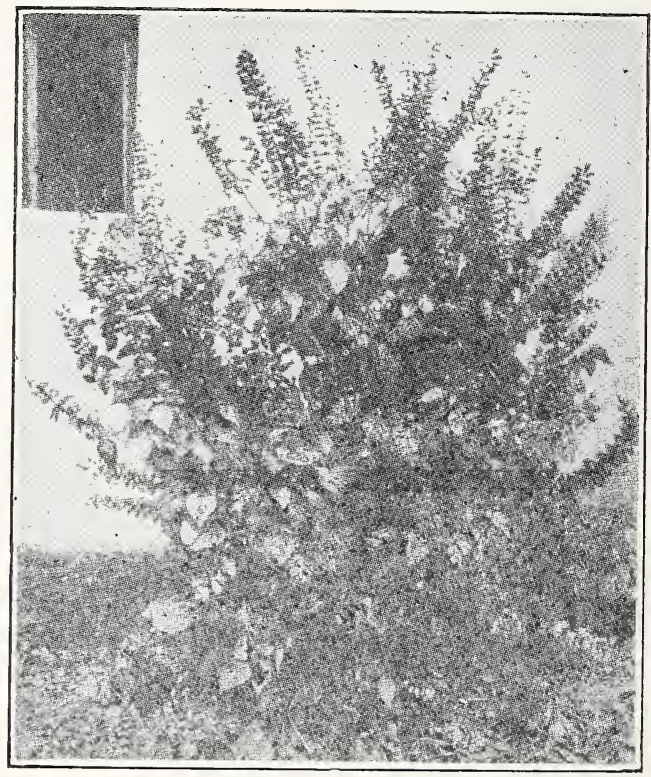

SALVIA SPLENDENS

arranged in spikes and are very fragrant. Colors are white, shell-pink and rich dark purple.

VERBENAS - This well-kn $\bullet$ wn plant makes an ideal bedder. Very few plants will make such a gorgeous display or furnish more flowers for cutting than the verbena. A few plants in the porch box or hanging basket adds beauty with its bright flowers. The large trusses of flowers are freely borne and are of almost every color imaginable.

VIOLET (Princess of Wales)-This is the largest of all violets. Flowers, single and rich violet blue. Easier to grow than the double and better adapted to Florida climate.

ZINNIAS-This plant, with its large double flowers in assorted colors, is becoming more popular each year, both as a bedder and a cut-flower. The daintiest colors are the different shades of pink, yellow and white, which are very attractive as vase flowers or for floral work. while the brighter colors make the yards very showy and pleasing to look upon. Especially fine for vase flowers for the cemetery on account of their keeping qualities. 


\section{Seeds}

AGERATUM-A fine half-hardy annual of easy culture, nice for bouquets (a delicate blue color). Pkg. 5c. Cover seeds 1-16 inch deep.

ASTER-One of the most popular and effective plants of the flower kingdom. Tall mixed, pkg. 5c; Dwarf Mixed, pkg. 5c; New branching, pkg. 10c; Aster King, pkg. 10c. Cover seeds $1 / 8$ inch deep.

BACHELOR'S BUTTON - Hardy annual of easiest culture; produces a fine effect in groups or masses. Mixed, pkg. 5c. Cover seeds $1 / 8$ inch deep.

BALSAM-Double Camellia Flowered. A general favorite, best effect is obtained when used in beds. Pkg. 10c. Cover seeds $1 / 4$ inch deep.

BRACHYCOME-Swan river daisy, has fern-like foliage and handsome flowers. Pkg. 5c. Cover seeds $1 / 8$ inch deep.

CARNATION - Needs no introduction to flower lovers. Mixed colors, pkg. $20 \mathrm{c}$. Cover seeds $1 / 8$ inch deep.

CARNATION, Marguerite-S m a $1 \mathrm{le} \mathrm{r}$ than above, but very free bloomer. Mixed colors, pkg. 10c. Cover seeds $1 / 8$ inch deep.

CALENDULA - Double yellow flower's, free-flowering, hardy annual. Pkg. 10c; $1 / 2$ oz. 25c.; 1 oz. 40c. Cover seeds $1 / 8$ inch deep.
CALLIOPSIS - Handsome showy annual of brilliant colors. Mixed, pkg. $10 \mathrm{c}$. Cover seeds 1-16 inch deep.

CANDYTUFT - Exceedingly fine for low borders. Mixed colors, pkg. 10c; white, plig. 10c. Cover seeds $1 / 8$ inch deep.

CANTERBURY BELLS-Very effective border plant. Single mixed, pkg. 10c. Cover seeds 1-16 inch deep.

CHRYSANTHEMUMS-Annual, mixed varieties, bright colors, pkg. 10c. Cover seeds $1 / 8$ inch deep.

COCKSCOMB-Very showy annual producing large heads of rich crimson and yellow flowers. Pkg. 10c. Cover seeds 1-16 inch deep.

Cosmos-Mixed colors, beautiful annual, rapid growth of 4 to 6 feet in height; fine for cut-flowers. Pkg. 10c. Cover seeds $1 / 4$ inch deep.

CYPRESS VINE-A delicate and beautiful climber; flowers resemble red and white stars. Pkg. 10c. Cover seeds 1/4 inch deep.

DAISY-Double mixed, trellis or English Daisy; fine for small border during winter season in Florida. Pkg. 10c. Cover seeds 1-16 inch deep.

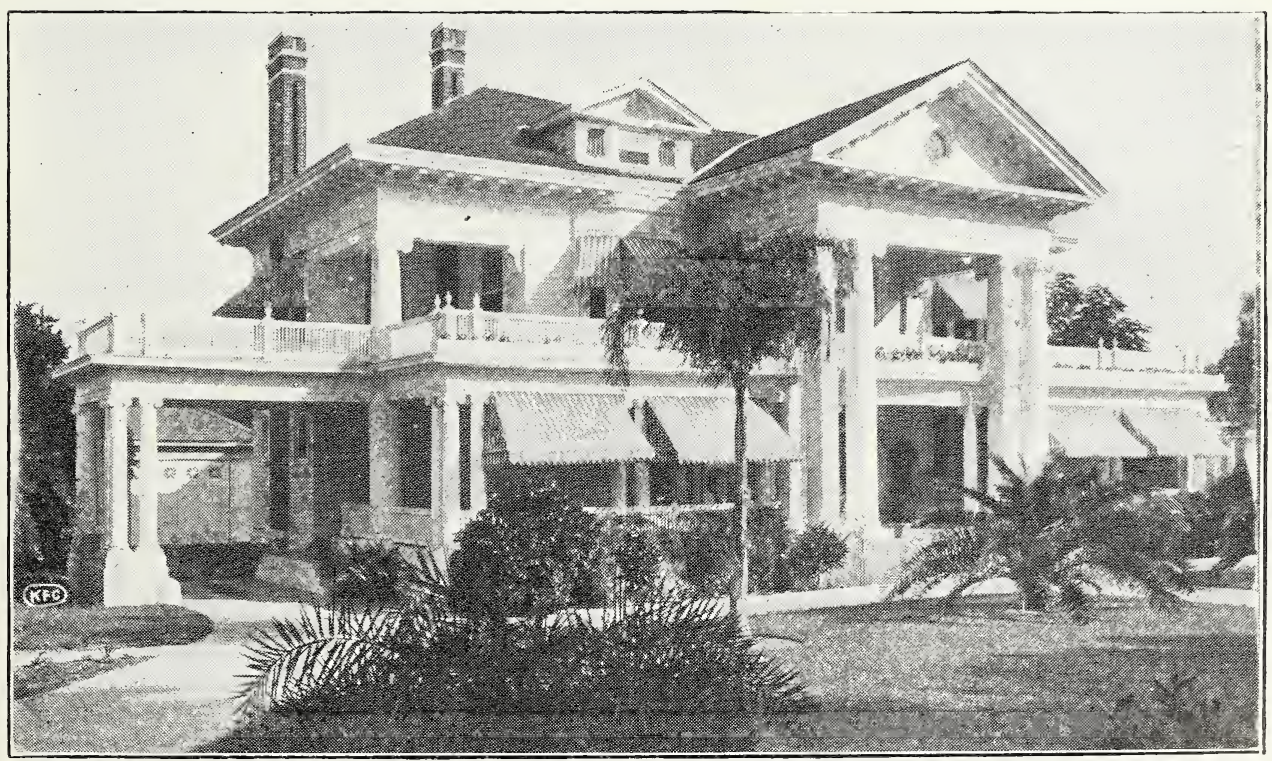

Page Thirty-Three 
KNULL FLORAL COMPANY, TAMP, FLORIDA

\section{SEEDS - Continued}

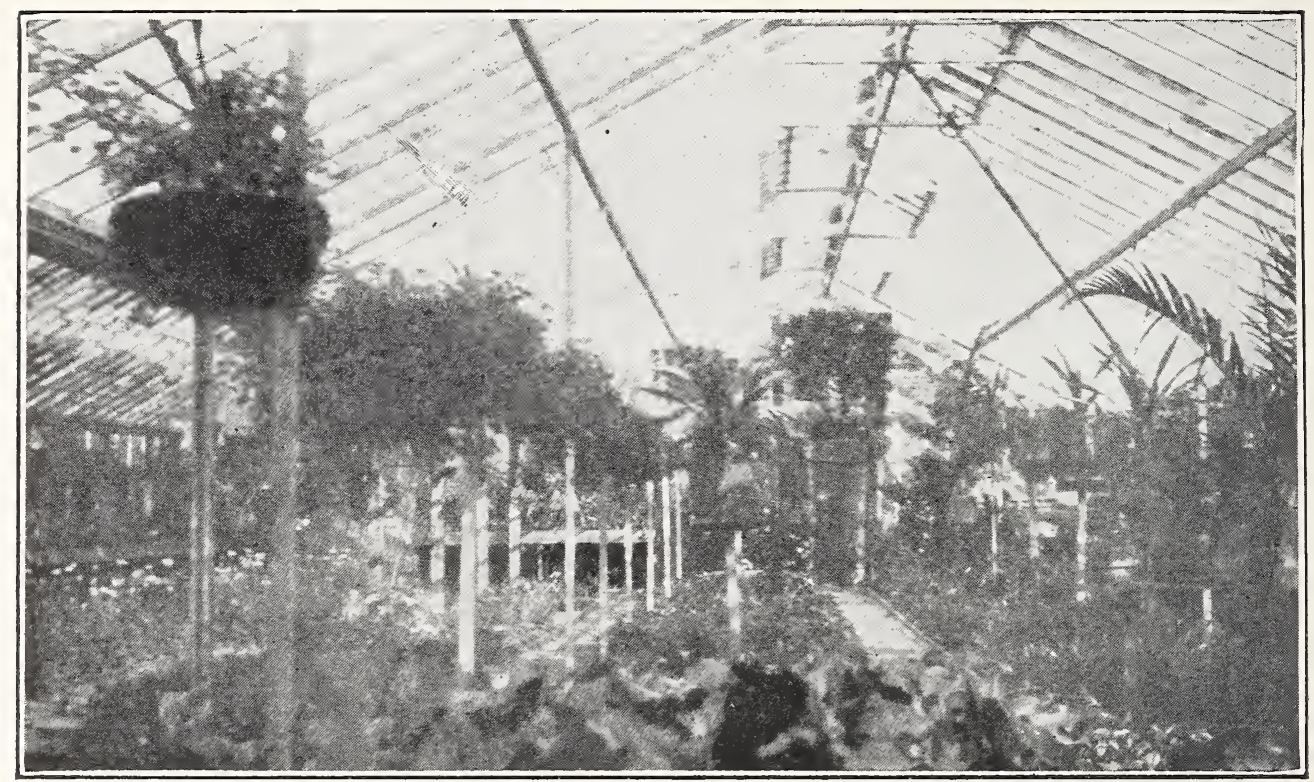

\section{INTERIOR OF ONE OF OUR GLASS HOUSES}

DATURA - Strong growing plants attaining a height of 2 to 3 feet. Mixed varieties, pkg. 5c. Cover seeds $1 / 4$ inch deep.

EVENING PRIMROSE-A showy plant opening its flowers only in the evening. Pkg. 10c. Cover seeds 1-16 inch deep.

EVENING GLORY-An adjunct to the old Morning Glory, a quick-growing vine bearing large white flowers in the evening. Pkg. 10c. Cover seeds 1 inch deep.

EVERLASTINGS - M i x e d varieties, pkg. 10c. Cover seeds $1 / 8$ inch deep.

FORGET-ME-NOT - An old favorite; succeeds best in a cool moist situation. Pkg. 10c. Cover seeds 1-16 inch deep.

FOUR O'CLOCK-Flowers are of many varied colors and are produced in great profusion. Pkg. 5c. Cover seeds $1 / 2$ inch deep.

GAILLARDIA-Handsome flowers very useful for making bouquets. Mixed colors, pkg. 10c. Cover seeds 1/8 inch deep.

GLOBE AMERANTH - Soak seed in warm water before planting; is an everlasting, sometimes called English clover. Pkg. 10c. Cover seeds $1 / 8$ inch deep.

HOLLYHOCK - Finest double mixed, including all the old favorite varieties. Pkg. 10c. Cover seeds $1 / 4$ inch deep.
HYACINTH BEAN - A rapid growing summer climber bearing large clusters of showy purple and white flowers. Pkg. 10c. Cover seeds 1 inch deep.

LARKSPUR - Double branching, giving an abundance of flowers suitable for vases and bouquets. Pkg. 10c. Cover seeds $1 / 8$ inch deep.

LOVE IN A MIST-Free flowering hardy annual; flowers are of very curious and peculiar construction. Pkg. 10c. Cover seeds $1 / 8$ inch deep.

MARIGOLD-French dwarf, being too well known to need description. Pkg. $5 \mathrm{c}$.

MARIGOLD - African mixed; taller growing than the French dwarf and larger flowering, mostly yellow in color. Pkg. 5c.

MIGNONETTE-A well known favorite, highly esteemed for its delightful fragrance. Pkg. 5c. Cover seeds $1 / 4$ inch deep.

MORNING GLORY-Rapid climber of dense foliage, an old and popular favorite. Pkg. 5c. Plant seeds $1 / 2$ inch deep.

MORNING GLORY - Royal Jap, the cultivation and hybridizing of the Morning Glory is a specialty of the Japanese and this improvement over the older favorites is marked. Pkg, 10c. 


\section{SEEDS}

MOURNING BRIDE or SCABIOSA-

Flowers range in color from white to almost black, are very pretty and useful for bouquets. Pkg. 10c. Cover seeds 1/8 inch deep.

NASTURTIUM - Tall, mixed colors, pkg. $15 \mathrm{c} ; 1 / 4$ lb. $40 \mathrm{c} ; 1 / 2$ lb. $75 \mathrm{c} ; 1$ lb. $\$ 1.25$.

NASTURTIUM - Dwarf, mixed colors, pkg. $15 \mathrm{c} ; 1 / 4$ lb. $50 \mathrm{c} ; 1 / 2$ lb. $80 \mathrm{c} ; 1 \mathrm{lb}$. $\$ 1.50$. Cover seeds $1 / 2$ inch deep.

NEMOPHILA-A genus of very pretty annuals deserving extensive cultivation. Pkg. 10c. Cover seeds $1 / 8$ inch deep.

NICOTIANA AFFINIS - A variety of Tobacco cultivated for its handsome sweet-scented flowers. Pkg. 10c. Cover seeds $1 / 8$ inch deep.

PANSY-Choice mixed; no garden is complete without them; fine for winter flowering in Florida. Pkg. 10c. Cover seed $1 / 8$ inch deep.

PANSY-Fancy mixed, finest show varieties. Pkg. 20c.

PETUNIA-Hybrid mixed colors, excedingly hardy, free blooming; will last through a whole season. Pkg. 5c. Cover seeds 1-16 inch deep.

PETUNIA-Veined and mottled; very ornamental; equally well adapted to garden or pot culture. Pkg. 10c.

PETUNIA-Large fancy flowered; seed in this packet are of the Grandiflora or large flowering type only. Single, fringed. Pkg. 20c,

PHLOX DRUMMONDI - No plant is more generally useful; it is without doubt the finest annual in cultivation. Pkg. 10c. Cover seeds 1/2 inch deep.

PHLOX (Star of Quedlinburg) - A very attractive variety of Phlox, each petal ending in a point which gives the flower a star-like form. $\mathrm{Pkg}$. $10 \mathrm{c}$.

PINKS-One of the best and most useful of flowering plants; double imperial. Pkg. 5c. Cover seeds 1/8 inch deep.

POPPY - Mixed varieties. Nothing causes more or greater admiration than this most showy and brilliant of annuals. Pkg. 5c. Cover seeds 1-16 inch deep.

POPPY (California) - Mixed colors; very profuse flowering plants of extremely rich colors. Pkg. $10 \mathrm{c}$.

PORTULACA-Double mixed. A very attractive and popular annual of creeping habit; succeeds best in sandy soil

\section{Continued}

and full sun. Pkg. 10c. Cover seeds 1-16 inch deep.

RICINUS-Castor oil plant; very ornamental and effective for a plant of large quick growth. Pkg. 5c. Cover seeds 1/2 inch deep.

SALVIA SPLENDENS - Flowers are brilliant scarlet borne on long spikes, blooms profusely. Cover seeds $1 / 8$ inch deep. Pkg. 10c; 1/4 oz. 60c; $1 / 2$ oz. $\$ 1.00$.

SALPIGLOSSIS-Large flowering, mixed; a very desirable plant deserving of more general cultivation. Cover seeds 1-16 inch deep. Pkg. 10c.

SCARLET FLAX - One of the handsomest annuals in cultivation; valuable for bedding. Pkg. 5c. Cover seeds 1/8 inch deep.

SNAPDRAGON - Finest tall mixed; one of the very best perennials and it is sure to give satisfaction. Cover seeds 1-16 inch deep. Pkg. 10c.

STOCK-Ten Weeks-Dwarf, as near a pefect flowering plant as any; fragrant flower's of almost every color. Pkg. 10c. Cover seeds $1 / 8$ inch deep.

SUNFLOWER-Very hardy and very double; closely resembles a large double chrysanthemum. Cover seeds $1 / 2$ inch deep. Pkg. $5 \mathrm{c}$.

SWEET PEAS-Very fragrant and desirable for cut flowers. Cover seeds 2 inches deep. Pkg. prices according to size, 5c in separate colors, in mixed colors $5 \mathrm{c}$ and $10 \mathrm{c}$ per package.

SWEET WILLIAM - Mixed colors, an old and popular variety, mostly used for mixed flower borders. Cover seeds $1 / 8$ inch deep. Pkg. 10c.

SWEET SULTA.N-Mixed colors; now very popular in Europe; flowers are thistle-like in appearance and deliciously fragrant. Cover seeds $1 / 2$ inch deep. Pkg. $10 \mathrm{c}$.

THUNBERGIA-A very free flowering climber, with handsome foliage and pretty flowers; mixed varieties. Cover seeds $1 / 2$ inch deep. Pkg. $10 \mathrm{c}$.

VERBENA - Choice mixed, very nice for beds, borders or porch boxes; very brilliant colors. Cover seeds $1 / 8$ inch deep. Pkg. 10c.

ZINNIA-Double mixed, flowers resemble those of the Dahlia, in very brilliant colors; they are the most satisfactory annual for planting in Florida. Cover seeds $1 / 4$ inch deep. Pkg. 10c.; 1/8 oz. 20c; 1/4 oz. $40 \mathrm{c} ; 1 / 2$ oz. $75 \mathrm{c} ; 1$ oz. $\$ 1.25$. 
KNULL FLORAL COMPANY, TAMP, FLORIDA

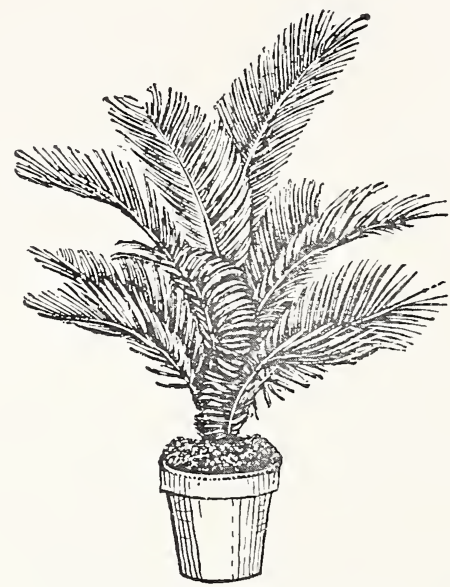

SAGO PALM POTTED

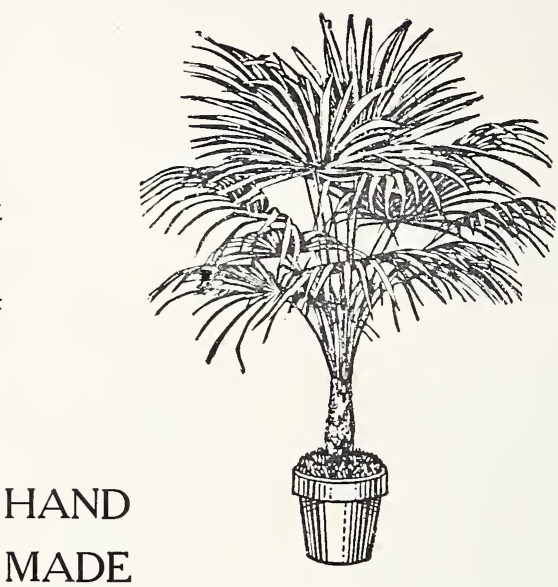

\section{PALM PLANTS POTTED}

Height Leaves Each Height Leaves Each 18 in. $\quad 10 \quad \$ 1.50 \quad 24$ in. $\quad 8 \quad \$ 1.50$

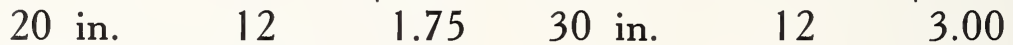
22 in. $\quad 18 \quad 3.00 \quad 36$ in. $\quad 18 \quad 4.00$ 24 in. $\quad 24 \quad 5.00 \quad 48$ in. $22 \quad 5.00$ ARTIFICIAL BOXWOOD TREES

\section{CONICAL}

Height Price

(1)

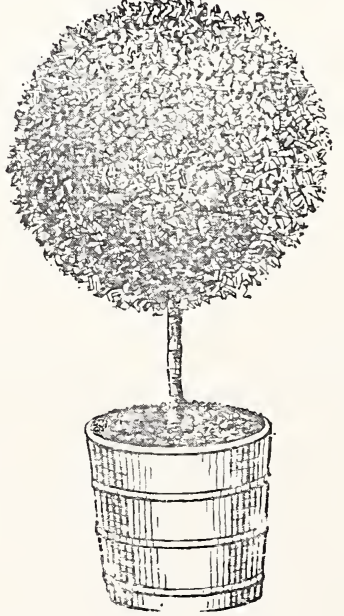

24 in. $\$ 7.00$

30 in.

9.25

36 in. 12.50

42 in. $\quad 15.00$

\section{ROUND}

Height Price 24 in. \$ 6.25 30 in. $\quad 8.00$ 36 in. 10.25 42 in. 12.50

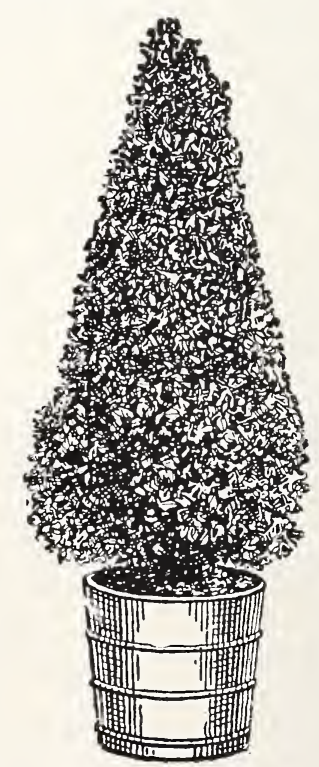




\section{ARTIFICIAL PALMS}

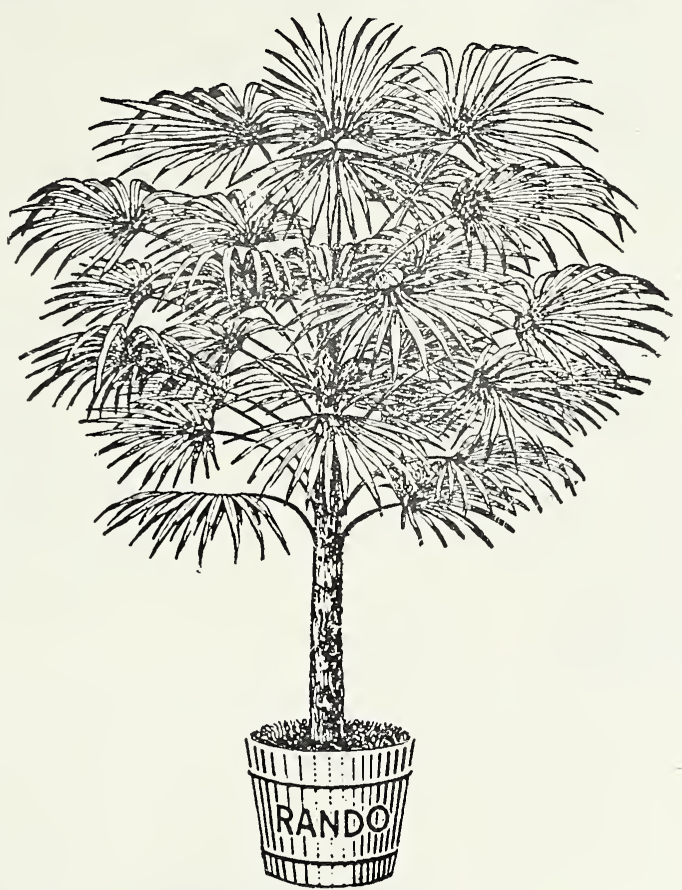

The most satisfactory plants for use in permanent decorations in stores, restaurants, halls, lodge rooms, or any place where plants have to remain in a dark place. They are made from natural Florida Palm leaves which have been cured and prepared, then painted; will retain their color for years. When they bscome covered with dust you may clean them by merely setting them outside and turning the hose on and giving them a good washing with a heavy spray from the nozzle. Our plants are all hand made and we use all possible care to make them appear just like the natural palm.

Palm Trees, $\left\{\begin{array}{rcr}\text { Height } & \text { Leaves } & \text { Each } \\ 5 \text { feet } & 12 & \$ 6.00 \\ 7 \text { feet } & 14 & 7.20 \\ 7 \text { feet } & 18 & 9.60 \\ 12 \text { feet } & 24 & 12.00 \\ 14 \text { feet } & 36 & 15.00\end{array}\right.$




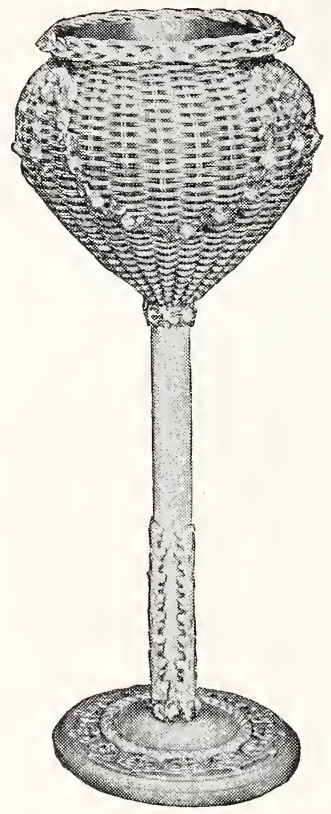

\section{BEAUTIFUL}

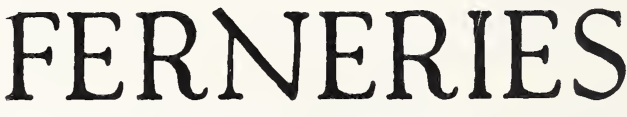

add much to the appearance of a home. They give a touch of Mother Nature right inside your living room, when filled with our live growing flowers, plants and ferns. Try one. You will be convinced.

Our Ferneries are very well made of the very best quality material and by the best basket-makers in the country; every care is used in their construction to make them as near perfect as it is humanly possible to do.

All P L A N T ST A NDS and F e r neries are e q u i p p ed with metal liners.

Pric e s range from $\$ 13.00$ and up, according to the design and size of the individual piece selected. We will be $\mathrm{glad}$ to have you call and inspect our line of Baskets and Ferneries.

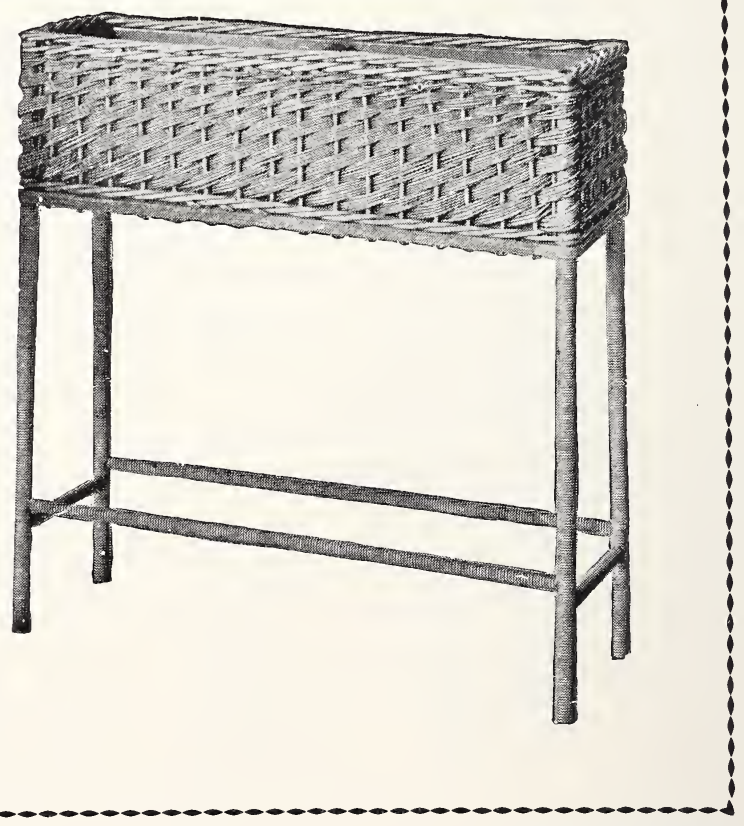

Page Thirty Eight 
KNULL FLORAL COMPANY, TAMP, FLORIDA

\section{F E R T I L I Z E R S}

THE KIND YOU WANT TO GROW BEAUTIFUL LAWNS, FLOWERS AND FOR THE SMALL HOME GARDEN

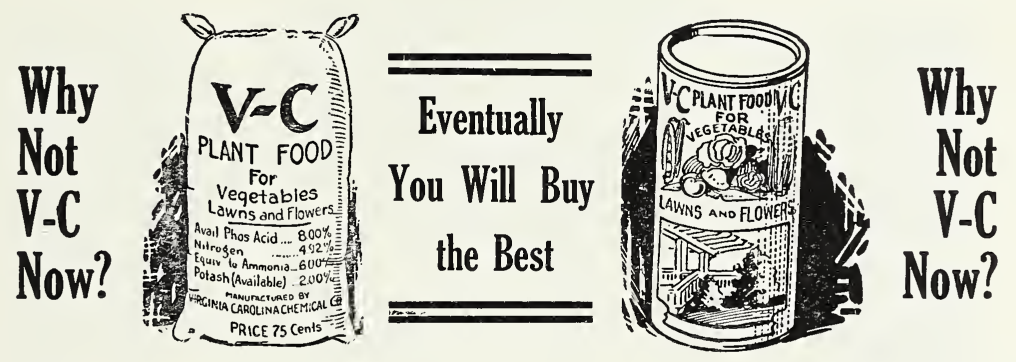

Put up in packages as follows: $1 \mathrm{lb}$. cans, $5 \mathrm{lb}$. bags, $10 \mathrm{lb}$. bags

\section{KNULL'S SPECIAL MIXTURE}

(Guaranteed Analysis)

AMMONIA, not less than 6 per cent

Derived from blood and bone, castor pomace, nitrate of soda and sulphate of ammonia.

AVAILABLE PHOSPHORIC ACID, not less than. 6 per cent Derived from bone and dissolved bone phosphate.

POTASH, actual (K2O), not less than 1 per cent

Derived from sulphate of potash and tobacco.

CHLORINE, not to exceed. 1 per cent MOISTURE, not to exceed. .12 per cent 
KNULL FLORAL COMPANY, TAMP, FLORIDA

\section{"SAY IT WITH FLOWERS"}

\section{FOR ALL OCCASIONS}

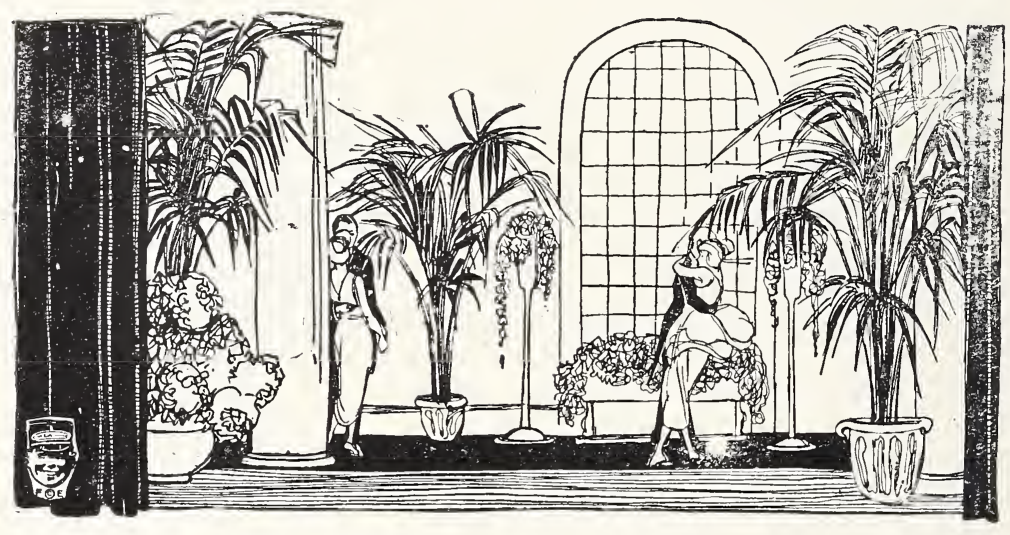

WE CARRY A COMPLETE LINE OF CUT-FLOWERS

AT ALL TIMES

Every seasonable flower is to be had at our store as soon as it comes into the market.

We make a specialty of bouquets and decorations for weddings and all social functions. Consult us. We are here to serve you. It is our pleasure to please you.

\section{KNULL FLORAL CO.}

408 TAMPA ST.

PHONE 2516 
KNULL FLORAL COMPANY, TA MA, FLORIDA

\section{MOGUL BRAND GARDEN HOSE}

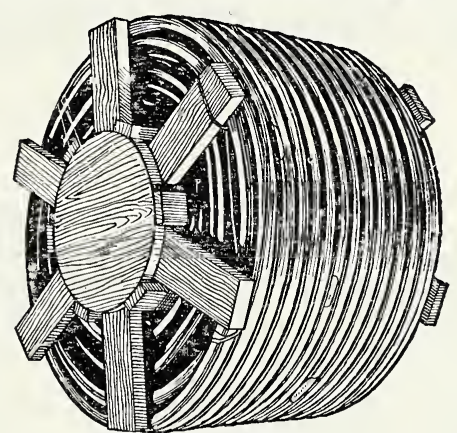

GUARANTEED FOR ONE YEAR

This Hose has been tested in our own plant and we have made sure of its high quality before offering it for sale. It will give you value received for every cent invested and several years' service if given ordinary good care.

Every home should have a string of garden hose for watering plants, shrubs, flowers, etc. They are an absolute necessity.

\section{LAWN MOWERS}
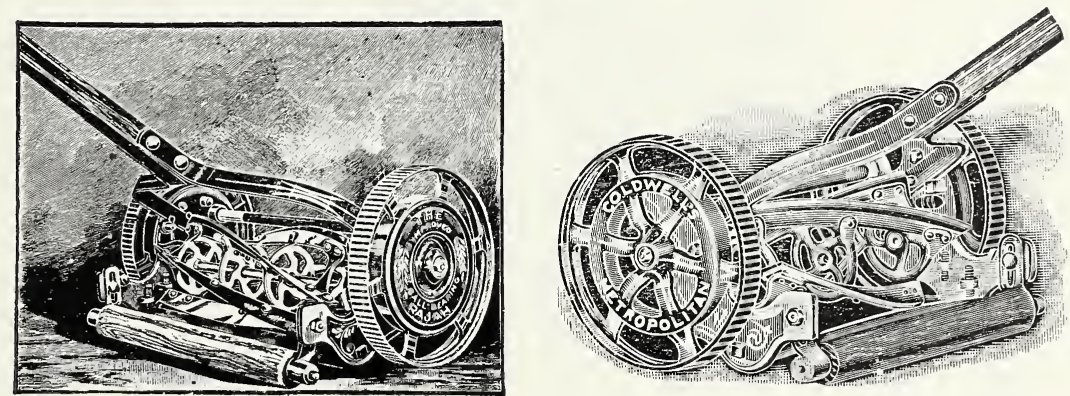

16-inch-5 Blades

COLDWELL HIGH WHEEL

14-inch-4 Blades

16-inch-4 Blades

NEWPORT

18-inch-4 Blades

14-inch-4 Blades

$\$ 11.75$

12.25

13.00

JEWEL

$\$ 10.50$

10.85

18-inch-4 Blades 11.20 
KNULL FLORAL COMPANY, TAMPA, FLORIDA

\section{We Are Distributors}

\section{Double Rotary Sprinkler}

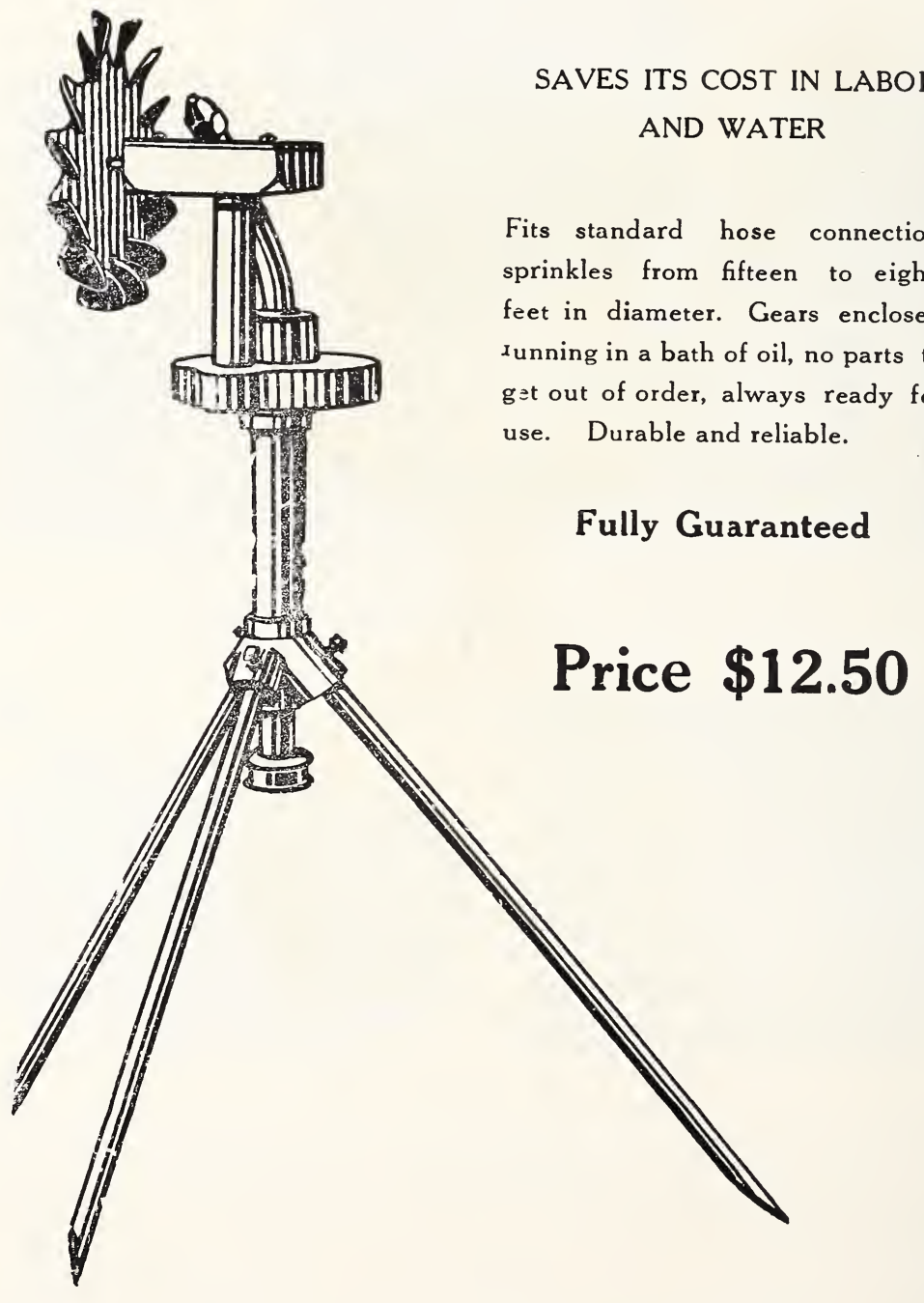

Sold on Ten Day's Free Trial 
KNULL FLORAL COMPANY, TAMPA, FLORIDA

\section{IRON RESERVOIR VASES}

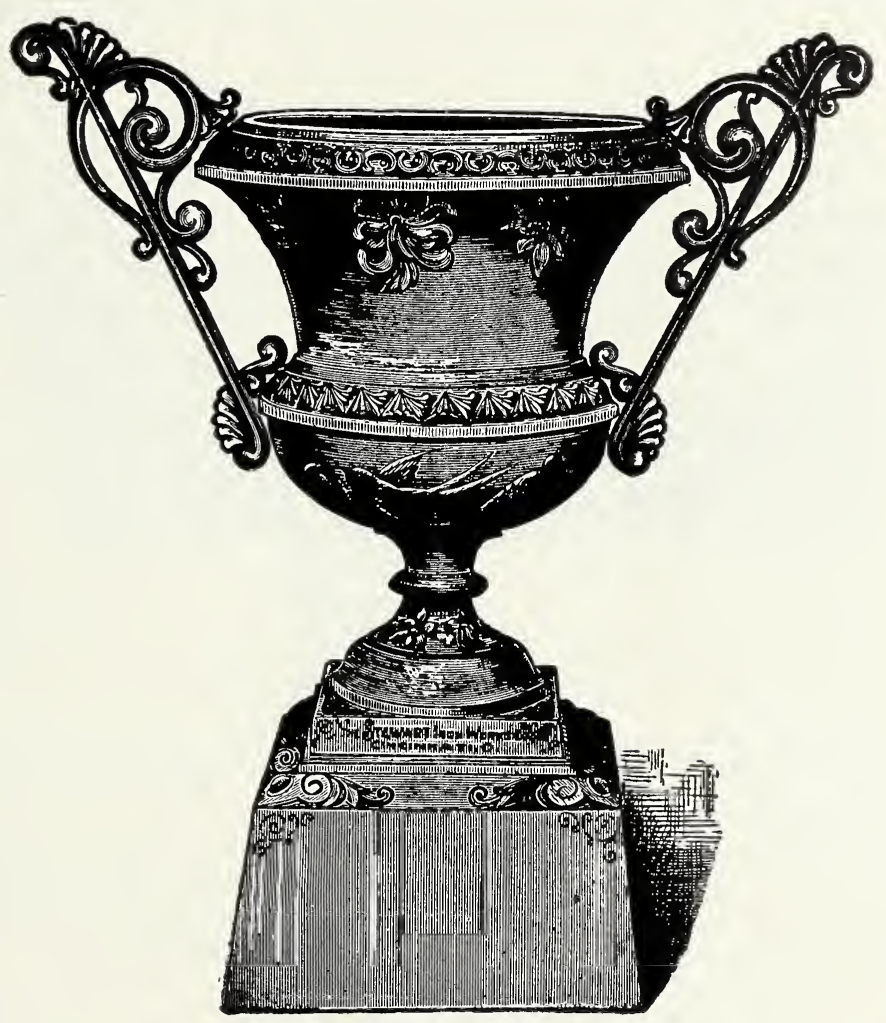

No. W-17, 21/2 Gallon Reservoir Automatic Watering

These Iron Reservoir Vases are made of cast iron and are very durable, the supply of water needs replenishing only about every fifteen days. Keeps your plants in a fresh growing condition.

CONCRETE VASES.

WRITE FOR PRICES. 
KNULL FLORAL COMPANY, TA MPA, FLORIDA

\section{PORCH BOXES}

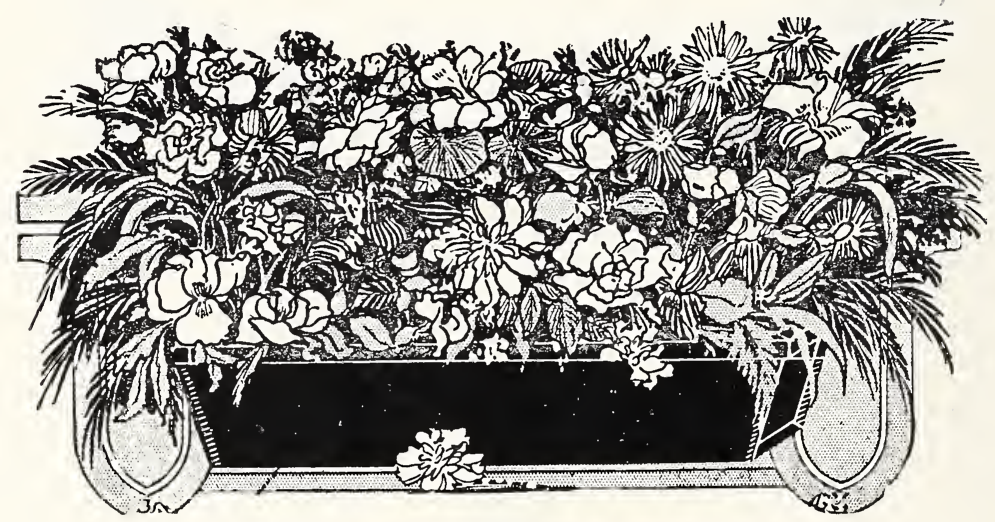

THEY MAKE YOUR HOME APPEAL

to every one who loves the beauties of nature and causes your home to seem almost a part of nature's work.

Our PORCH BOXES are made from good quality cypress lumber one inch thick, painted green, and under ordinary conditions will give several years' service. Price 75 cents per foot, including soil.

\section{HANGING BASKETS}

We carry a complete line of Hanging Baskets at all times in both terra cotta and wire. Terra cotta, greeston finish, $35 \mathrm{c}$ to $\$ 3.50 \mathrm{each}$, according to size, hangers included. Wire Baskets, according to size, each $35 \mathrm{c}, 50 \mathrm{c}, 75 \mathrm{c}$ and $\$ 1.00$, including hangers. 
KNULL FLORAL COMPANY, TAMPA, FLORIDA

\section{RAFFIA}

\section{ALL COLORS - 15 and 25c Per Package NATURAL - - - 50c Per Pound}

2 -inch
$21 / 2$-inch $\ldots \ldots \ldots \ldots \ldots \ldots \ldots \ldots$

FLOWER-POT SAUCERS SAME PRICE AS POTS GENUINE CEDAR TUBS, PAINTED INSIDE AND OUT 
KNULL FLORAL COMPANY, TAMPA, FLORIDA

\section{Vases and Settees}

\section{Made of Iron \\ Especially for Your Grounds}
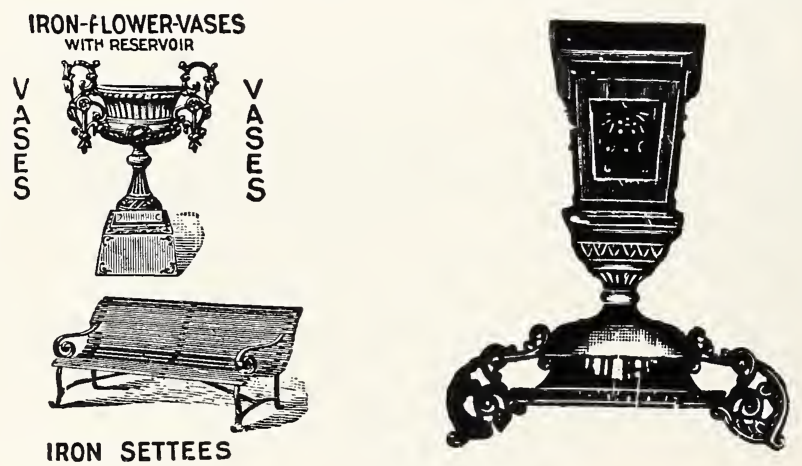

The great feature of the Vases is their automatic watering process, which gives plants just the right quantity of water at all times. This is accomplished by a double bottom, the upper one for the earth and plants, and the lower one for the water. The water is drawn up as needed by capillary attraction through a tube filled with pebbles, moss or sponge, into the earth above.

Just stop and consider what this wonderful devise means to you. You need not worry about watering the flowers every morning or evening; in fact, you can go away for two weeks and find your plants in better shape when you come back than when you went away. 
KNULL FLORAL COMPANY, TAMPA, FLORIIA

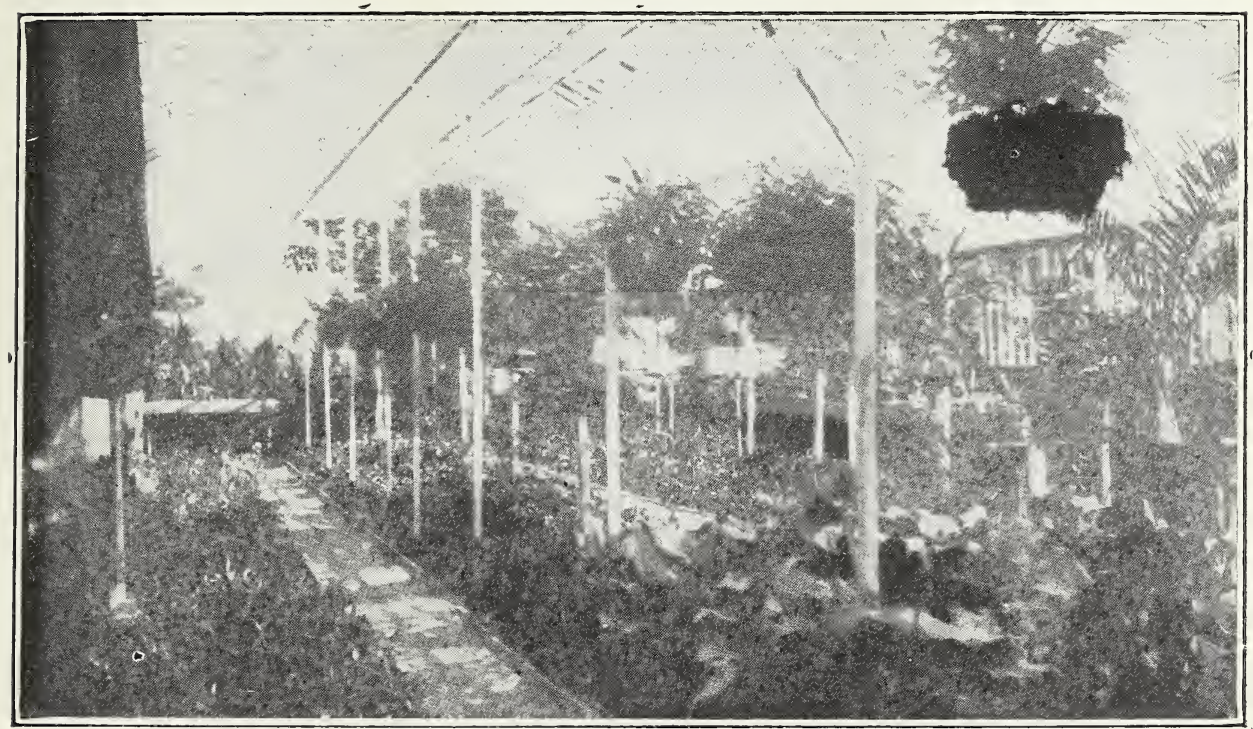

INTERIOR OF ONE OF OUR GREENHOUSES 




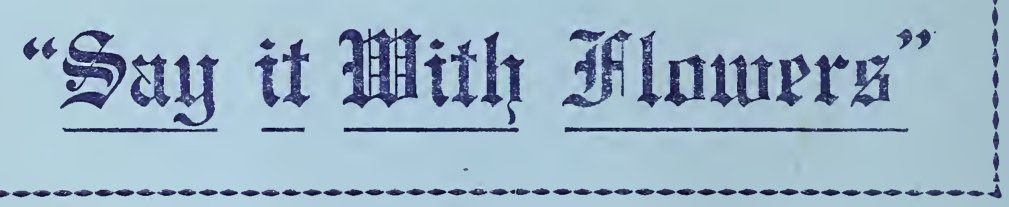

